\title{
Decades needed for ecosystem components to respond to a sharp and drastic phosphorus load reduction
}

\author{
Ingrid Chorus $(\mathbb{D}) \cdot$ Antje Köhler $\cdot$ Camilla Beulker $\cdot$ Jutta Fastner $•$ \\ Klaus van de Weyer • Tilo Hegewald • Michael Hupfer (1)
}

Received: 21 September 2019/Revised: 10 October 2020/Accepted: 20 October 2020/Published online: 8 November 2020

(C) The Author(s) 2020

\begin{abstract}
Lake Tegel is an extreme case of restoration: inflow treatment reduced its main external phosphorus (TP) load 40-fold, sharply focused in time, and low-P water flushed the lake volume $\approx 4$ times per year. We analysed 35 years of data for the time TP concentrations took to decline from $\approx 700$ to $20-30 \mu \mathrm{g} / \mathrm{l}$, biota to respond and cyanobacteria to become negligible. The internal load proved of minor relevance. After 10 years, TP reached $35-40 \mu \mathrm{g} / \mathrm{l}$, phytoplankton biomass abruptly declined by $50 \%$ and
\end{abstract}

Guest editors: Tom Jilbert, Raoul-Marie Couture,

Brian J. Huser \& Kalevi Salonen / Restoration of eutrophic lakes: current practices and future challenges

Electronic supplementary material The online version of this article (https://doi.org/10.1007/s10750-020-04450-4) contains supplementary material, which is available to authorised users.

I. Chorus $(\bowtie) \cdot$ C. Beulker $\cdot$ J. Fastner

German Environment Agency, Schichauweg 58,

12307 Berlin, Germany

e-mail: ingrid.chorus@gmail.com

A. Köhler

Berlin Senate Department for the Environment, Transport and Climate Protection, Am Köllnischen Park 3,

Berlin 10179, Germany

C. Beulker

Landeslabor Berlin Brandenburg; Presently Federal Environment Agency, Schichauweg 58, 12307 Berlin,

Germany cyanobacteria no longer dominated; yet 10 years later at $\mathrm{TP}<20-30 \mu \mathrm{g} / \mathrm{l}$ they were below quantifiable levels. 20-25 years after load reduction, the lake was stably mesotrophic, macrophytes had returned down to 6-8 $\mathrm{m}$, and vivianite now forms, binding $\mathrm{P}$ insolubly in the sediment. Bottom-up control of phytoplankton through TP proved decisive. Five intermittent years with a higher external $P$ load caused some 're-eutrophication', delaying recovery by 5 years. While some restoration responses required undercutting thresholds, particularly that of phytoplankton biomass to $\mathrm{TP}$, resilience and hysteresis proved irrelevant. Future research needs to focus on the littoral zone, and for predicting time spans for recovery more generally, meta-analyses should address $\mathrm{P}$ load reduction in combination with flushing rates.

K. van de Weyer

Lanaplan, Lobbericher Str. 5, 41334 Nettetal, Germany

T. Hegewald

Department Water Quality, State Reservoir

Administration of Saxony, Bahnhofstraße 14,

01796 Pirna, Germany

M. Hupfer

Department of Chemical Analytics and Biogeochemistry, Leibnitz Institute for Freshwater Ecology and Inland Fisheries, Müggelseedamm 301, 12587 Berlin, Germany 
Keywords Restoration - Phosphorus - Sediment . Plankton $\cdot$ Macrophytes $\cdot$ Cyanobacteria

\section{Introduction}

Since Vollenweider (1976) first published the OECD study on eutrophication of inland waters, the basis for focusing eutrophication control strategies on reducing phosphorus $(\mathrm{P})$ loads was a wide consensus on the validity of Liebig's law of the minimum factor determining the maximum possible standing stock of biomass. Measures to reduce and reverse eutrophication have been implemented worldwide since the 1980s and are taking effect: in an increasing number of waterbodies trends of trophic state are reversing towards re-oligotrophication (e.g. Anneville et al., 2002; Jeppesen et al., 2005; Morabito et al., 2005; Hilt et al., 2010a, b; Evans et al., 2011; Fastner et al., 2016;). Not all lake restoration attempts have successful, and the debate has re-emerged whether it is sufficient to control only the loads of $\mathrm{P}$ or whether it is necessary to also reduce those of nitrogen $(\mathrm{N})$, i.e. whether we need a dual strategy (Schindler, 2012; Paerl et al., 2019). Arguments brought forth for a dual strategy include that (i) while internal loading through $P$ release from the sediments may render reducing external $\mathrm{P}$ loads ineffective, $\mathrm{N}$ has the advantage of being permanently lost from the system through denitrification; (ii) when $\mathrm{P}$ becomes limiting in the epilimnion, the vertical migration of taxa such as Microcystis spp. allows them to replenish their P cell quotas and continue to form blooms, and (iii) excessive nitrate concentrations have a detrimental impact on aquatic macrophytes (Olsen et al., 2015) which-if present-could bind nutrients that otherwise would fuel phytoplankton proliferation (Scheffer, 1989).

Sterner (2008) partially reconciles the debate by pointing to the relevance of scales in time and space for such considerations: while for short time scales of days and weeks within a seasonal cycle resources other than $\mathrm{P}$ frequently limit phytoplankton growth, he concedes that in the longer term control through $\mathrm{P}$ limitation may be effective; nonetheless he calls for further examination of the paradigm for "phosphorus limitation of whole lakes at multi-annual scales". For shallow lakes, Jeppesen et al. (2007) address the question whether "we need to push the system" in the recovery phase (e.g. through biomanipulation) because of mechanisms acting against a response to reduced loads, i.e. internal $\mathrm{P}$ loading from the sediments and resilience of the biota, i.e. the stability of established populations and ecological interactions resisting change. Mantzouki et al. (2016) also emphasise the significance of high historical loads that may continue to cause blooms for many years, calling for a case by case approach to evaluate whether or not it is sufficient to focus control only on P.

Chorus \& Spijkerman (2020) critically review the proposed need for a dual strategy mentioned above and find that while focusing on one nutrient is sufficient, $\mathrm{N}$ load reduction may be the method of choice for a quick response of some shallow lakes. In face of the doubts about the success of a focus on $\mathrm{P}$ or on one nutrient, it is interesting that Jeppesen et al. (2007), analysing data from 56 shallow lakes, found that phytoplankton biomass declined quite directly following reduction of total phosphorus (TP); in consequence these authors propose hysteresis to be of lesser importance than previously anticipated. For stratified lakes and reservoirs, however, no overarching analysis of restoration responses similar to that of Jeppesen et al. (2007) is available. While some analyses of large data sets including up to hundreds of waterbodies are available (e.g. Phillips et al., 2008; Carvalho et al., 2013 or Richardson et al., 2018), these have evaluated phytoplankton biomass relative to TP at a given points in time rather than having studied change over time within the waterbodies. Their results are useful for setting nutrient concentration targets to be achieved by load reduction. However, analyses of time sequences of individual lakes are necessary for understanding whether or not reducing the load only of phosphorus is sufficient, which in-lake response to expect, which mechanisms stabilise a given state or composition of biota and thus possibly cause resistance to re-oligotrophication-and the time spans for which such mechanisms may be relevant.

For this purpose, Lake Tegel in Berlin, Germany, provides the rare opportunity of a case study with an unusually pronounced reduction of its P load, sharply focussed at a point in time, and this after an unusually long loading history. In many European lakes, eutrophication accelerated during the 1960s when an increasing number of households were connected to sewage systems but treatment did not yet include the removal of phosphate; also the widespread 
introduction of washing machines using laundry detergents based on polyphosphate complexing agents approximately doubled the $\mathrm{P}$ loads from human excreta (Zessner, 1999). However, in Lake Tegel eutrophication began yet earlier: starting at the end of the 19th century the lake received sewage effluent, modestly treated on sewage farms which were rapidly overloaded as the city's population steeply increased. Secchi disc readings, since their availability in the mid-1950s, were never above $2 \mathrm{~m}$, indicating hypertrophic conditions already back then. Massive summer blooms of cyanobacteria (particularly Microcystis spp.) were common, and anaerobic conditions in the hypolimnion sometimes caused oxygen depletion up to $3 \mathrm{~m}$ depth when thermal stratification was very stable.

This urban lake is intensively used for recreation and as source for the drinking of the north-west of the city, serving around 400000 inhabitants with water abstracted from wells around the lake shore via bank filtration. In the 1970s, concern increased that infiltration of the high organic load caused by heavy eutrophication might eventually compromise the removal processes to a point where the use of the lake as drinking water resource would not be sustainable (later research showed that the Berlin underground removes biogenic contaminants quite effectively, as water takes several weeks to travel through mostly fine sands until it reaches the drinking water wells; Chorus et al., 1992). This concern triggered investment into a phosphorus elimination plant (PEP) that went into operation in late 1984 and strips $P$ from the lake's main inflow.

This key measure for the restoration of Lake Tegel reduced the load of TP from the main tributary very quickly, i.e. more than 10-fold within the 1st year and in the longer term by a factor of 40 (Heinzmann \& Chorus, 1994; Schauser et al., 2006a). This restoration approach was based on the assumption that exchanging the lake's water volume 3-4 times per year with water containing not more than $20 \mu \mathrm{g} / \mathrm{l} \mathrm{TP}$ would be sufficient to shift the lake to a mesotrophic state within a few years. However, at the time the PEP was installed, in face of the lake's previous loading history and its sapropelic black sediments, pronounced scepticism was voiced by some as to whether this measure would be sufficiently effective, or whether resilience mechanisms of different ecosystem components would be strong enough to maintain the hypertrophic state for many further years.

Meanwhile, data on nutrients, physical parameters and biota are available for Lake Tegel from more than 3 decades of research and monitoring by the Federal Environment Agency, the Leibnitz Institute for Freshwater Ecology and Inland Fisheries as well as the Berlin Senate with the State Laboratory Berlin-Brandenburg. In the following we analyse these data to identify the time spans necessary for the response of key ecosystem components to the pronounced P load reduction, including the relevance of lag phases and turning points for responses of ecosystem components. We address the number of years necessary for the $\mathrm{P}$ exchange between sediments and water to reach a new steady state and the number of years necessary for the reduced $\mathrm{P}$ concentration in the lake to cascade through trophic levels until responses of the biota (phytoplankton, zooplankton, macrophytes, mussels) became visible. This analysis includes interactions of ecosystem components and their relevance for trophic recovery as well as changes still occurring in the fourth decade after load reduction. We use these data to test the following hypotheses:

1. Reducing the TP load is sufficient provided both the load reduction and the water residence times undercut critical thresholds; this given, there is no need for concomitant reduction of the $\mathrm{N}$ load or any other "push of the system" (e.g. through biomanipulation).

2. Some delay in responses (resilience) is to be expected from sediment rich in legacy $\mathrm{P}$ in the sediment and through prevalence of established biota (e.g. high amounts of Microcystis likely to survive winter and inoculate summer populations) or the absence thereof (e.g. of propagules to seed macrophyte regrowth). This will delay responses but not to an extent requiring further measures.

\section{Methods and study site}

\section{Lake Tegel}

With almost $4 \mathrm{~km}^{2}$ surface area, Lake Tegel is one of Berlin's larger lakes. Two main tributaries feed this thermally stratifying lake at its north-eastern shore. Along its south-western shore Lake Tegel is connected 
to the Havel River which is impounded $5 \mathrm{~km}$ further downstream (Fig. 1). The amount of Havel River water that enters the lake strongly depends on the inflow from the tributaries at the north-east which drain agricultural land and carry high amounts of treated sewage. As the above-mentioned sewage irrigation fields were starkly overloaded and no longer sufficiently effective even in reducing the organic load, in 1986 they were replaced by a sewage treatment plant. While denitrification was still fairly effective on the sewage irrigation fields, the sewage treatment plant introduced nitrification only in 1992 and denitrification in 1996. This increased the epilimnetic concentrations of dissolved inorganic nitrogen (DIN) to several $\mathrm{mg} / \mathrm{l} \mathrm{N}$, as ammonia from 1986 until the summer of 1992 and since then as nitrate (Supplementary Material, Fig. S.1). Even after these measures were implemented, epilimnion concentrations of nitrate-N remained above $0.5 \mathrm{mg} / \mathrm{l}$. Limitation of phytoplankton by nitrogen can therefore be excluded (Reynolds, 1997; Dolman et al., 2012). However, between 1987 and 2000 denitrification processes sometimes caused nitrite concentrations in the range of $0.2-0.5 \mathrm{mg} / \mathrm{l}$ within the lake, i.e. an order of magnitude above those known to damage fish (Table 1).
Restoration measures

\section{Reduction of the phosphorus load}

The key restoration measure was to strip phosphorus from the lake's two main tributaries at the northeastern end of the lake. The process chosen is highly effective as it not only precipitates $\mathrm{P}$ with iron or aluminium chloride and/or sulphate salts (as commonly done in sewage treatment) but also includes a filtration step, thus achieving mean annual effluent concentrations in the range of $19-24 \mu \mathrm{g} / \mathrm{l}$ of $\mathrm{P}$ since 1988 (Heinzmann \& Chorus, 1994). According to the Vollenweider (1976) model, at the water exchange rate of 75-80 days assumed at the time, this corresponds to a load of $1.5 \mathrm{~g} \mathrm{P}$ per $\mathrm{m}^{2}$ surface area and year, which should be sufficiently low to attain concentrations in the lake in the range of $30 \mu \mathrm{g} / \mathrm{l}$ (Klein, 1992).

Two conditions were recognised to be critical for achieving this target load: one is maintaining a minimum rate of water exchange with the low-P water from the PEP in order to control Havel River water intrusion at the south-west end of the lake. The other is to ensure that stormwater overflows exceeding the capacity of the PEP can bypass the lake because these
Fig. 1 Lake Tegel, its characteristics, tributaries and position of the phosphorus elimination plant (PEP) (from the Berlin Waterbody Atlas)

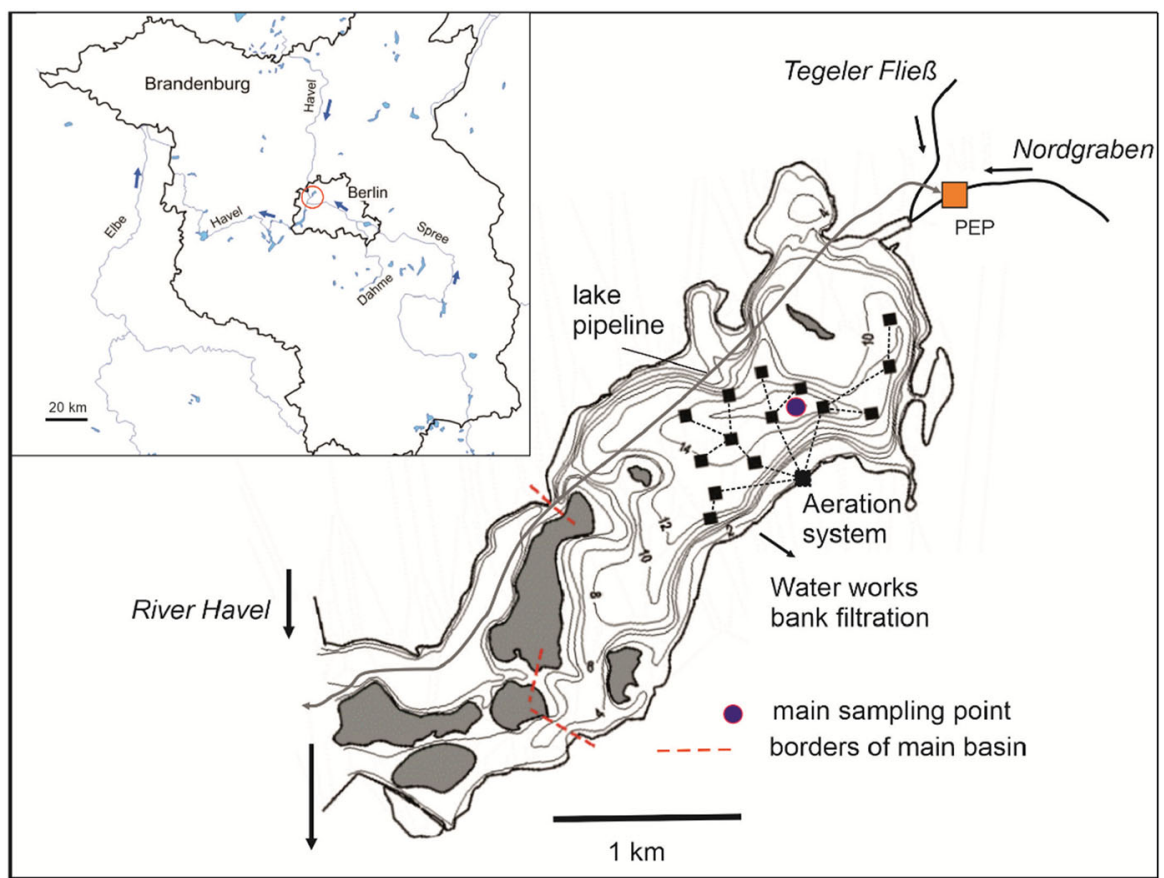


Table 1 Morphometric characteristics of Lake Tegel

\begin{tabular}{ll}
\hline Parameter [unit] & Lake Tegel \\
\hline Surface area $\left[\mathrm{km}^{2}\right]$ & 3,96 \\
Maximal area of hypolimnion $\left[\mathrm{km}^{2}\right]$ & 1,47 \\
Lake volume $\left[10^{6} \mathrm{~m}^{3}\right]$ & 26.12 \\
Maximal volume of hypolimnion $\left[10^{6} \mathrm{~m}^{3}\right]$ & 5.28 \\
Maximum depth $[\mathrm{m}]$ & 16 \\
Water residence time [d] & $50-100$ \\
\hline
\end{tabular}

*(Schimmelpfennig et al., 2012)

could carry substantial P loads within a few hours. For both purposes, a pipe was laid through the lake with a capacity of $6 \mathrm{~m}^{3}$ per second, which went into operation together with the PEP in autumn of 1984. This pipe can work both ways, i.e. either transport excess water from the tributaries directly to the Havel River or-in times of insufficient flow from the tributariesit can carry river water to the PEP. While diverting excess inflow has rarely been necessary, due to changes in the catchment delivering less water to the PEP the pipe has become important for maintaining a sufficient inflow to the PEP. Inflow to the PEP was thus established at $2.8-3 \mathrm{~m}^{3}$ per second.

However, costs of operating the PEP are not negligible: Heinzmann \& Sarfert (1990) approximated the costs for the PEP, including capital costs, at that time to $0.09-0.18 €$ per $\mathrm{m}^{3}$ of treated water. To economise, between 1997 and 2002 the operators experimented with reducing the throughflow, i.e. to $1.3-1.5 \mathrm{~m}^{3} / \mathrm{s}$. At that time, it was unclear how much more untreated, P-rich Havel River water would then enter the lake at the south-western end, increasing the $\mathrm{P}$ load again. In consequence of the experience gained during those years (discussed below), since 2002 the PEP has been operated at $2.3-2.4 \mathrm{~m}^{3} / \mathrm{s}$ as annual mean, but with higher levels of $2.7-3.2 \mathrm{~m}^{3} / \mathrm{s}$ during summer. Furthermore, from 2017 onward and until advanced sewage treatment will be implemented to remove trace substances, PEP operation has been reduced again, to $1.5-2.2 \mathrm{~m}^{3} / \mathrm{s}$ in order to reduce concentrations of traces of pharmaceuticals from sewage effluent in the catchment, as a few of these compounds are not well retained by bank filtration and travel into the drinking water wells (Schimmelpfenning et al., 2016). These fluctuations in the amount of
low-P water entering the lake have offered interesting opportunities to study the lake's responses.

\section{Aerator operation}

A measure taken at Lake Tegel already in 1980 was aeration, at the time with the target of remediating oxygen depletion, which had started to reach water levels up to $3 \mathrm{~m}$ (Heinzmann \& Chorus, 1994). The 15 bubble plume aerators installed in the main basin successfully increased oxygen concentrations, but during the 1980s they also substantially destabilised thermal stratification (Lindenschmidt \& Chorus, 1997) and increased water temperatures above the sediment, thus enhancing mineralisation of organic matter, which in turn releases P. Aeration was continued even after the PEP went into operation, based on the assumption that this would counteract the release of redox sensitively bound $\mathrm{P}$ from the sediments. However, chemical analyses of $\mathrm{P}$ fractions in the sediment (performed in 1994 and in 2004) and laboratory experiments showed this process to be of minor relevance relative to rapid $\mathrm{P}$ release through mineralisation (Schauser et al., 2006b) and in relation to the P balance of the lake (Kleeberg et al., 2012). Because of the negative effect of instable stratification for the P supply of epilimnion, aerator operation was reduced since 1989 and their design modified. In consequence, since 1992 Lake Tegel develops rather stable thermal stratification with an epilimnion of 5-8 $\mathrm{m}$ depth and temperature gradients of $12^{\circ} \mathrm{C}$ and more during summer (Fig. S.2 in the Supplementary Material), and in sufficiently cold winters ice cover may develop. While oxygen depletion continues to occur in the hypolimnion for a few weeks in late summer, since 1995 the aerators are switched on only for short periods of time (about 2 weeks) in late summer if conditions in the hypolimnion become so anoxic that they start threatening fish habitats, in particular through elevated concentrations of nitrite. This exerts little influence on thermal stratification.

\section{Methods}

Although funding for research and monitoring of the lake's development fluctuated during this time span, basic nutrient and phytoplankton data are available continuously, both from monitoring by the Berlin city 
government and from a range of research projects, diploma- and PhD-theses. Since 2002 the Berlin city government has contracted the State Laboratory Berlin-Brandenburg (LLBB) to continue the time series of depth profiles for physical, chemical and biological data.

\section{Sampling}

Sampling was conducted at monthly to weekly intervals, varying between programmes and thus between years (for some parameters and in some years only from May through October) at a buoy marking the deepest site in the lake's main basin. Up to 2006 UBA also sampled 2 sites between the islands close to the lake's connection to the Havel River. The results for physical and chemical parameters showed that for an overall assessment of restoration responses the data from the deepest site of the main basin are sufficient, as the data follow the same patterns over time and very similar quantities to those obtained at the deepest site (see Figure S.3, Supplementary Material).

For chemical parameters depth profiles were taken at intervals of $1 \mathrm{~m}$ by UBA from 1984 to 2006 and by LLBB at $0.5,7$ and $14 \mathrm{~m}$ as depths representative for the epi-, meta- and hypolimnion; in many years since 2002 LLBB has also been sampling profiles at intervals of $1 \mathrm{~m}$ from May to October. For phytoplankton biomass, both laboratories took samples at depth intervals in the epilimnion or euphotic zone and integrated them for quantitative evaluation (with a few cases where we use samples from $2 \mathrm{~m}$ to be representative of the epilimnion). In some years this was also the case for (Chl.a) (Fig. S.4 in the Supplementary Material shows $2 \mathrm{~m}$ to represent the epilimnion quite satisfactorily); in others we calculated integrals from depth-segregated samples. Zooplankton was sampled with a 4 L Limnos sampler, and Leptodora was sampled with a Hydrobios closing net $(40 \mu \mathrm{m}$ mesh size) and analysed following DIN EN 15110 (2006) and Tümpling \& Friedrich (1999).

Physical and chemical analyses

Temperature and oxygen depth profiles were measured with probes (WTW, Syland or YSI Multiparameter probe) following DIN 38404 part 4 for temperature and DIN 17289:2014 for oxygen. Secchi disc transparency was determined in the boat's shadow following EN ISO $7027 \mathrm{C} 2$. Total and soluble reactive phosphorus (TP, SRP) were determined following DIN EN ISO 15681-1 (D45). For nitrate, nitrite and ammonia LLBB followed DIN EN ISO 11732: 2005-05, DIN EN ISO 10304-1:2009-07 and DIN EN ISO 11732: 2005-05, respectively.

Chl.a was extracted with boiling ethanol and determined photometrically following ISO 10260 (1992; also DIN 38412- L16: 1985). However, in face of the occasional occurrence of negative values when correcting for phaeophytin especially at low levels of Chl.a, UBA dropped this step and re-calculated all data without this correction (in most cases the difference between both approaches is minor).

To ensure that data used by both laboratories gave coherent results that can be integrated for analyses over the decades they cover together, we compared data obtained by both labs in parallel, albeit during different weeks of the months, for periods of 10-20 years for Secchi disc transparency as well as for the seasonal means (May-October) of total phosphorus and Chl.a. Differences between both labs proved minor, and particularly for TP the data agree closely (see point 5 in the supplementary material for figures and more detail). Both labs participated in interlaboratory calibration.

Internal $\mathrm{P}$ balance and $\mathrm{P}$ status of the sediments

The mean $\mathrm{P}$ content in the lake and in the two different water layers $(0-8 \mathrm{~m}, 8-14 \mathrm{~m})$ were calculated using the TP and SRP concentration profiles at the deepest site and the volumes of the corresponding water layers. Sediment cores were taken in September 2015 with a modified Kajak sampler (UWITEC) at the deepest site. The cores were sliced in $1 \mathrm{~cm}$ layers one for radioisotopic dating with ${ }^{137} \mathrm{Cs}$ and ${ }^{210} \mathrm{~Pb}$ and one for elemental determination of 19 selected layers (details see Senate, 2017). In six layers of a third core, $\mathrm{P}$ forms were determined by sequential PSENNERfractionation (see Hupfer et al., 2016). Vivianite occurrence was detected by visual inspection of freeze-dried samples under the light microscope. The development of $\mathrm{P}$ retention was estimated by the TP content multiplying with the dry mass accumulated over the respective time period. 
Plankton and fish

Phytoplankton taxa were determined to the species level where possible. For quantification, Cryptophyceae and Microcystis were not further differentiated at UBA (while LLBB determined up to the species level). Centric diatoms were evaluated only within size classes (in steps of $5 \mu \mathrm{m}$ at LLBB and in 3 categories $(<5 \mu \mathrm{g}, 5-15 \mu \mathrm{m}$ and $>15 \mu \mathrm{m}$ diameter $)$ at UBA) unless they occurred as filaments (see below). Cell density was counted using an inverted microscope following Utermöhl (1958) at up to 400-fold magnification, counting at least 400 cells of the 3-5 dominant taxa and at least 2 transects of a sedimentation chamber; if results of these 2 transects deviated by more than 20 per cent, a third transect was counted. Colonies of Microcystis were either disintegrated with ultrasound so that single cells could be counted (UBA), or they were quantified as sub-colonies with cell number estimates (LLBB). Filamentous species were either evaluated by measuring the total length of the parts of the filaments within the transect (UBA) or by counting segments of $10 \mu \mathrm{m}$ length (LLBB). Biovolumes were calculated from cell numbers multiplied by mean cell volumes which were obtained by measuring the necessary dimensions from 10 to 20 cells of the respective taxon per sample and approximating geometric models or using standard mean cell volumes.

Zooplankton was evaluated following the methods published by Horn \& Horn (1995) and described in detail in the PhytoLoss manual by Deneke et al. (2015).

Yields of commercial fisheries were taken from the annual reports to the Berlin Fisheries authority of data on species and biomass caught.

\section{Macrophytes}

Following the PHYLIB method (Schaumburg et al., 2015) 16 transects of 20-30 m width were surveyed semiquantitatively by divers in 2012, 2016 and 2019 along the lake shores, including those of the islands, in depths up to $10 \mathrm{~m}$, distinguishing zones of $0-1 \mathrm{~m}$, 1-2 m, 2-4 m, 4-6 m, 6-8 m, 8-10 m, etc. down to the lowest stands). Species were determined following van de Weyer \& Schmidt (2018). Findings were classified in 5 frequency categories following Kohler (1978). Ecological quality was assessed with two different approaches, i.e. the PHYLIB Method developed for implementation of the EU Water Framework Directive (updated by Schaumburg et al. 2015) which corresponds to DIN EN 15460 (2008) and combines quantity with abundance, and the Lanaplan (2006) approach which has been developed for calcium-rich lakes in the lowlands of northern Germany).

Data evaluation

For key parameters we discuss epilimnetic means $(0-5 \mathrm{~m})$ for May to September. Although the metalimnion is often deeper, we chose $5 \mathrm{~m}$ because concentrations of Chl.a show almost no difference between depths in this layer (Fig. S.4 in the Supplementary Material) and we could thus use the $2 \mathrm{~m}$ data to represent the whole layer for the years starting in 2009, for which no further epilimnion data are available. For assessing means from May to September, in face of the number of sampling occasions ranging between weekly in some years to monthly in others, we first calculated monthly means and from these the means and their standard deviations over these 5 months of the growing season (termed "summer means" in the following).

To identify regime shifts in the time series of TP and Chl.a, we chose the framework for testing for structural change in linear regression models proposed by Zeileis et al. (2002). Within the frame work, we applied a procedure detecting breakpoints in time series (Bai \& Perron, 2003; Zeileis et al., 2003) which selects the optimal number of breakpoints by means of the Bayesian information criterion. The computations were performed using the $\mathrm{R}$ system for statistical computing (R Development Core Team 2018).

\section{Results}

Response of phosphorus to reduced loading

After the pronounced load reduction in autumn of 1984 TP in the lake decreased rapidly, during the first 4-5 years exponentially (Fig. 2), and within 5 years, peak epilimnion concentrations of up to more than $800 \mu \mathrm{g} / \mathrm{l}$ decreased to less than $200 \mu \mathrm{g} / \mathrm{l}$. By 1993, the mean concentration in the epilimnion during May to September declined to $44 \mu \mathrm{g} / \mathrm{l}$ (for means, see the synopsis in Fig. 11). In 1994 the mean reached to 
$29 \mu \mathrm{g} / \mathrm{l}$, now clearly limiting the carrying capacity for phytoplankton biomass (see below). However, from 1997 to 2001, due to the reduction of PEP throughflow mentioned above, concentrations of $\mathrm{P}$ increased again, up to a summer mean of $65 \mu \mathrm{g} / \mathrm{l}$ in the year 2001 and with concentrations in winter exceeding $200 \mathrm{mg} / \mathrm{l}$. Since 2002, the seasonally optimised management regime described above reduced the load from the PEP during summer. Also, TP concentrations in the Havel River gradually declined by about a factor of 5-10 (Grüneberg et al., 2015), resulting in reduced loading from the intruding river water at the south-western end of the lake. In consequence, from 2002 until 2016 TP concentrations declined to summer means in the range of $20 \mu \mathrm{g} / \mathrm{l}$. The second phase of reduced PEP operation from 2017 to 2019 caused some increase in TP concentrations, with summer means of up to $29 \mu \mathrm{g} / \mathrm{l}$ $\mathrm{TP}$ and pronounced maxima again occurring in autumn.

The distinct TP peaks in autumn observed particularly during earlier years and during the 2 phases of reduced inflow of low-P water reflect the annual $\mathrm{P}$ accumulation in hypolimnion. However, these maxima in the hypolimnion are not quantitatively sufficient to explain the overall increase in the TP content of the whole lake, indicating loading from the Havel River, which shows seasonal patterns of TP similar to those in Lake Tegel (Fig. S.6 in the Supplementary Material).

Investigation of a sediment core dated back to approximately 1913 shows that during the years of pronounced eutrophication, $\mathrm{P}$ retention in the sediment was about three times lower than before and after this period (Table 2). The heavy pollution of Lake Tegel during the 1950-1980s is also evident in the higher content of heavy metals in these sediment layers, and this also predominantly originated from wastewater insufficiently treated on the sewage farms (Ladwig et al., 2017). In the more recent years with mesotrophic conditions (2006-2015), P retention (related to a lake area below $8 \mathrm{~m}$ and calculated from the data in Table 2) was about $5.3 \mathrm{t}$ per year. Interestingly, these higher retention rates under mesotrophic conditions associate with a distinctly higher $\mathrm{P}$ content of the sediment in the layers before $(>31 \mathrm{~cm})$ and after $(<15 \mathrm{~cm})$ eutrophication. These are mainly explained by higher BD-P and $\mathrm{NaOH}-\mathrm{SRP}$ contents in these layers (Fig. 3). In addition to the BD$\mathrm{P}$ fraction, the $\mathrm{NaOH}-\mathrm{SRP}$ fraction also represents mainly iron-bound $\mathrm{P}$ in this sediment, since the $\mathrm{Al}$ content of approximately $8 \mathrm{mg} \mathrm{g} \mathrm{dw}^{-1}$ in the P-rich layers is low and shows no pronounced variability over the last century. Thus, Al only has minor importance as $\mathrm{P}$ binding partner and for explaining the variability of the $\mathrm{NaOH}-\mathrm{SRP}$ fraction. This is strong evidence that $\mathrm{P}$ is primarily associated with reduced iron. The molar ratio of $\mathrm{S}: \mathrm{Fe}$ is lower $(<1)$ in horizons with high amounts of $\mathrm{NaOH}-\mathrm{SRP}$, whereas low $\mathrm{NaOH}-\mathrm{SRP}$ during the eutrophic period corresponds with molar $\mathrm{S}$ :Fe ratios $>1$. Under a light microscope dark-blue vivianite nodules are visible,

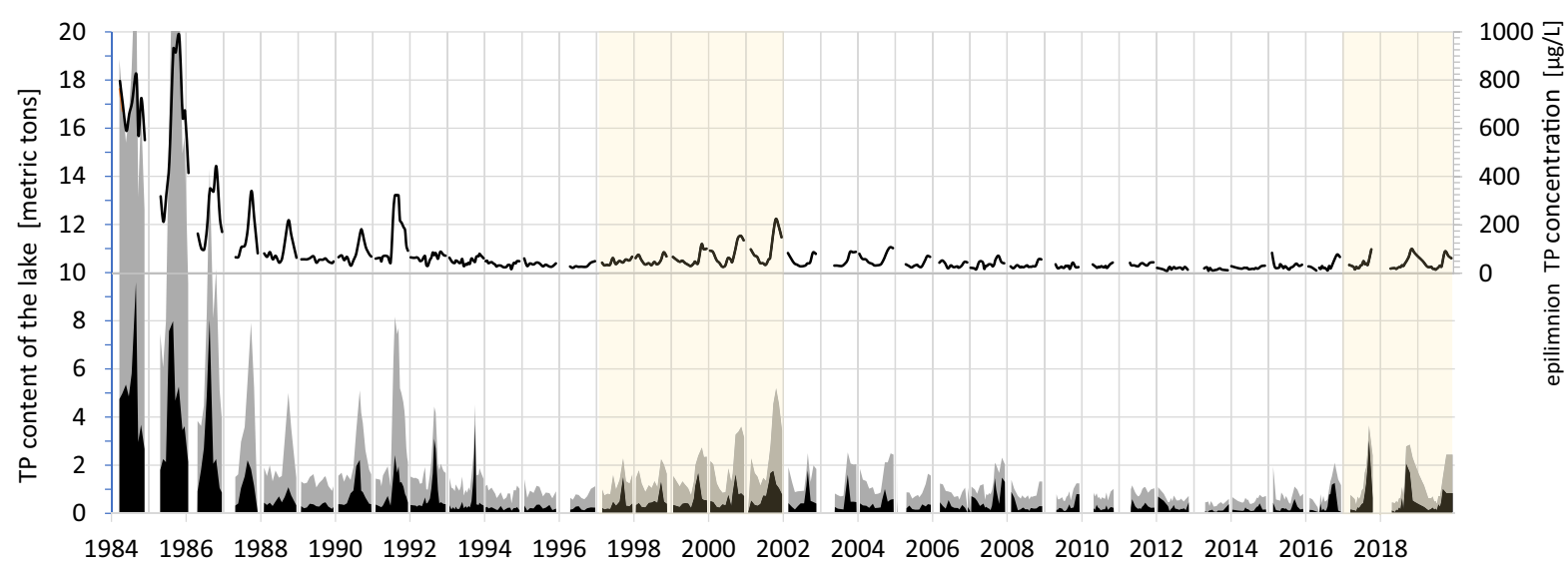

Fig. 2 Total Phosphorus development in Lake Tegel: Content in metric tons $(1,000 \mathrm{~kg}$, left-hand axis) for the total volume of the epilimnion ( $0-8 \mathrm{~m}$; grey areas) and the hypolimnion (8-14 $\mathrm{m}$; black areas) and concentrations in the epilimnion (solid curve, right-hand axis). Shaded areas show phases with reduced inflow of low-P water from the PEP. Note that curves and areas are interrupted where the data show gaps of more than 1 month 
Table 2 Phosphorus deposition rate calculated by a sediment core taken at the deepest site of Lake Tegel in September 2015

\begin{tabular}{ll}
\hline Period & $\mathrm{g} \mathrm{P} / \mathrm{m}^{2}$ year \\
\hline 2006-2015 & 3.6 \\
$1986-2005$ & 1.2 \\
$1966-1985$ & 0.8 \\
$1946-1965$ & 1.4 \\
$1913-1945$ & 5.4 \\
\hline
\end{tabular}

but only in horizons with high $\mathrm{NaOH}-\mathrm{SRP}$ content, i.e. those formed under mesotrophic conditions.

Response of phytoplankton to reduced phosphorus concentrations

\section{Nutrient limitation and phytoplankton biomass}

Phosphorus (P) limitation can be excluded for 1984-1987 because levels of soluble reactive phosphorus (SRP) ranged well above $100 \mu \mathrm{g} / \mathrm{l}$ (Fig. S.7, Supplementary Material) with the exception of only one sampling occasion each in 1986 and 1987, each too short-lived to impact the high levels of phytoplankton biomass. First signs of P limitation appeared in 1988 when epilimnetic concentrations during summer were frequently below $10 \mu \mathrm{g} / \mathrm{l}$-and in 1989 even below $2 \mu \mathrm{g} / \mathrm{l}$ for an extended summer phase. 1993 marks the beginning of a situation in which SRP concentrations above $10 \mu \mathrm{g} / \mathrm{l}$ were no longer observed in the epilimnion from early spring until autumn, indicating that the phytoplankton biomass had incorporated the readily available phosphorus. However, this alone does not yet imply $\mathrm{P}$ limitation of biomass as it is well known that depletion of dissolved nutrient concentrations merely limits the uptake rate of phytoplankton cells: with high amounts of $\mathrm{P}$ contained within the biomass, rapid recycling between lysing and growing cells will sustain that biomass and light rather than $\mathrm{N}$ or $\mathrm{P}$ is likely to be limiting further cell division.

In 1992 and 1993, the particularly high summer mean concentrations of Chl.a and biovolume relative to those of TP indicate maximum exploitation of TP by phytoplankton (dominated by Planktothrix agardhii), shortly before TP limitation started to set in in 1993 and 1994 (Fig. 5, panel C). In 1994, with TP concentrations down to a summer mean of $29 \mu \mathrm{g} / \mathrm{l}$, phytoplankton biomass declined quite abruptly to about half of the previous levels, both as summer mean and as maximum: Chl.a reached a maximum of "only" $27 \mu \mathrm{g} / \mathrm{l}$ rather than the range of 55-160 $\mu \mathrm{g} / \mathrm{l}$ observed in previous years (Fig. 4). Maxima of total phytoplankton biovolume remained below $10 \mathrm{~mm}^{3} / 1$ in contrast to the range of $20-40 \mathrm{~mm}^{3} / 1$ typical for previous years (Fig. 6) and summer means amounted to $4-6 \mathrm{~mm}^{3} / 1$ rather than the $6-15 \mathrm{~mm}^{3} / 1$ observed previously (see synopsis of parameters in Fig. 11). Breakpoint analysis for summer means of Chl.a identified 1994 as a change point in time at which phytoplankton first showed a pronounced response to restoration (Fig. S.8 in the Supplementary Material). It also identified 2008 as second change point, the beginning of a phase from 2008 to 2016 with rarely more than $5 \mathrm{~mm}^{3} / 1$ of biovolume and $8-10 \mu \mathrm{g} / \mathrm{l} \mathrm{Chl.a.}$ During this phase summer mean TP concentrations

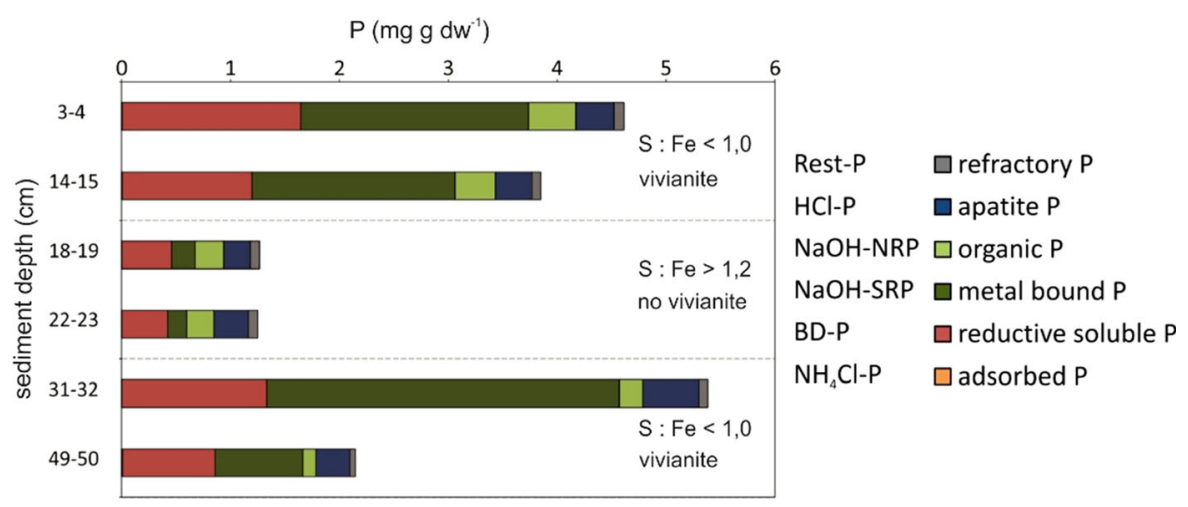

Fig. 3 Phosphorus fractions in a sediment core taken at the deepest point of Lake Tegel in September 2015. Dark-blue vivianite nodules were detected in horizons with molar S:Fe ratios $<1$. Layers deposited in different periods: after 1992 (upper), between 1948 and 1992 (middle) and before 1948 (lower). Modified from Heinrich (2016) 


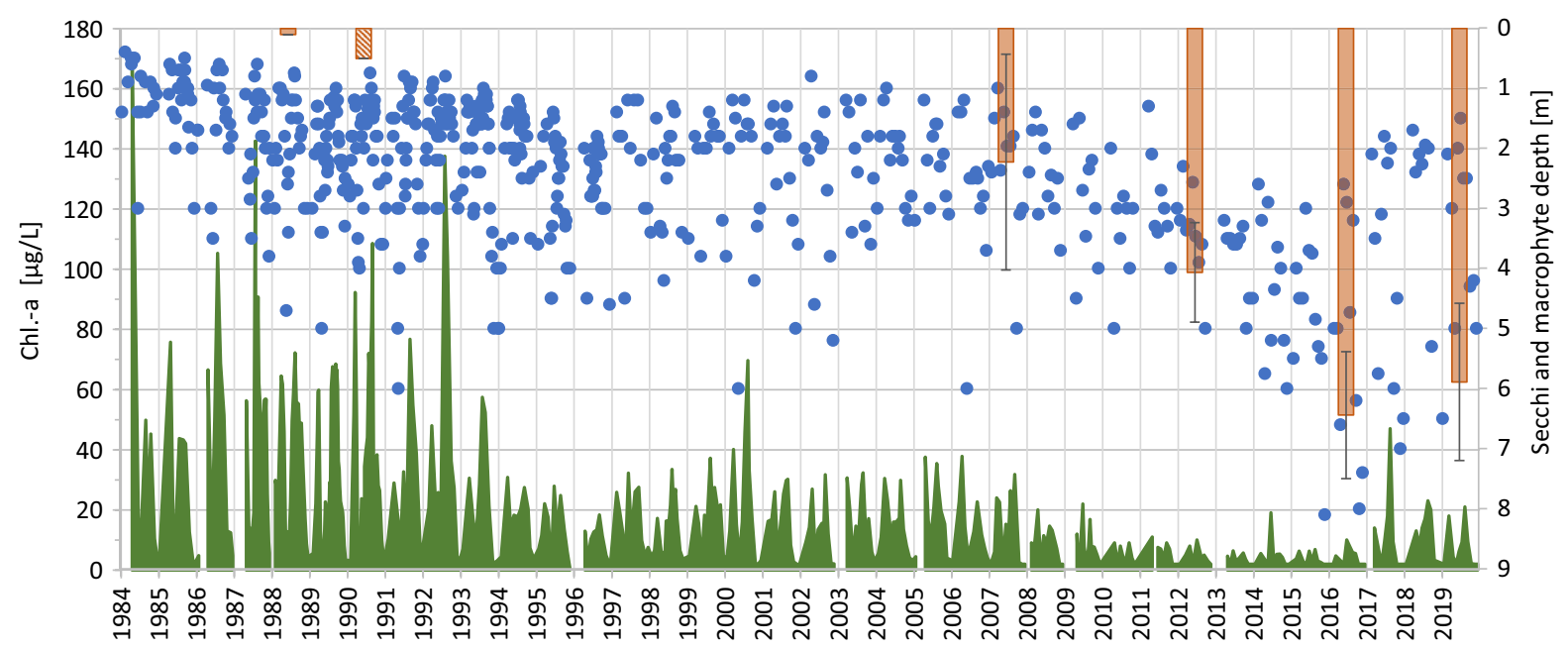

Fig. 4 Response of phytoplankton biomass (as mean chlorophyll-a in 0-5 m; green areas), transparency (Secchi disc readings; blue points) and macrophyte cover (bars with standard

between were yet lower, ranging between 20 and $30 \mu \mathrm{g} / \mathrm{l}$.

Following the classification of Vollenweider \& Kerekes (1982), this corresponded to a mesotrophic state. While in some years before 2006 spring maxima were higher than those observed during summer, this was no longer observed from 2007 onward. Instead, seasonal patterns of biomass-both as Chl.a and as biovolume-shifted from the bimodal pattern to a pattern with one maximum in summer, which Winder \& Sommer (2012) found to be a typical difference between eutrophic and mesotrophic lakes.

Summer mean epilimnetic concentrations of Chl.a plotted against those of TP and connected chronologically as "restoration response curve" (Fig. 5, upper panel) also show the threshold concentration of TP that the lake needed to undercut before phytoplankton biomass was significantly and sustainably reduced: Regression analyses, grouping the data by TP above or below $45 \mu \mathrm{g} / \mathrm{l} \mathrm{TP}$, confirm the threshold concentration identified with the breakpoint analysis: for summer mean TP $>45 \mu \mathrm{g} / \mathrm{l}$ Chl.a was independent of TP, indicated a slope of 0.02 and an $\mathrm{R}^{2}$ of 0.05 (Fig. 5, lower panel; see also Table S.1, Supplementary Material). Above $45 \mu \mathrm{g} / \mathrm{l}$, TP light was the most likely limiting resource, as nitrogen can be excluded (see above). In contrast, at mean summer TP concentrations below $45 \mu \mathrm{g} / \mathrm{l}$ we found a distinct relationship between Chl.a and TP with a slope of 0.77, explaining $58 \%$ of the variation, although mean summer TP deviation) as means of maximum coverage depths of transects (see Table 3); data for 1988 and 2007 from Hilt et al. (2010b)

concentrations varied only in the range $18-44$, i.e. by a factor of 2.4.

Figure 5 further shows that during the 5 years of renewed TP increase in 1997-2001 (points marked yellow), Chl.a increased, but not back to the levels previously attained at the same TP concentrations, suggesting some resilience during this short phase of re-eutrophication (see discussion). In contrast, during the second, less pronounced phase of re-eutrophication starting in 2017, Chl.a was in the upper range of concentrations observed in other years at the same TP levels.

\section{Phytoplankton species composition}

Cyanobacteria dominated the phytoplankton during Lake Tegel's hypertrophic phase from July until late autumn, chiefly Microcystis and Aphanizomenon, accompanied by large diatoms (Asterionella, Fragilaria, Diatoma and Aulacoseira). Before 1994, cyanobacteria regularly attained summer biovolume maxima between 10 and $20 \mathrm{~mm}^{3} / 1$, in 1987 even $30 \mathrm{~mm}^{3} / 1$ (Fig. 6) in integrated epilimnion samples and pronounced surface scums were frequent. Relative to TP, maxima of cyanobacterial biomass correlated with TP up to TP concentrations of about $50 \mu \mathrm{g} / \mathrm{l}$ and in a few cases up to $100 \mu \mathrm{g} / \mathrm{l}$ (Fig. 7), but at yet higher levels of TP no further increase was evident. The most conspicuous restoration response of species composition was the disappearance of cyanobacterial 
Fig. 5 Panel A: Restoration response curve, i.e. summer (May-Sept.) epilimnion $(0-5 \mathrm{~m})$ mean concentrations of chlorophyll-a (Chl.a) relative to those of total phosphorus (TP) connected chronologically from 1984 until 2019. The years during which TP increased again are marked yellow for 1997-2001 and red for 2016-2019; green and blue shading separates the euand hypertrophic phase from the mesotrophic phase; Panel B: Regressions for concentrations of Chl.a relative to those of $\mathrm{TP}$, splitting the data at $\mathrm{TP}=45 \mu \mathrm{g} / \mathrm{l}$; Panel C: Ratios of phytoplankton biomass (as Chl.a and as biovolume, $\mathrm{BV}$ ) to $\mathrm{TP}$
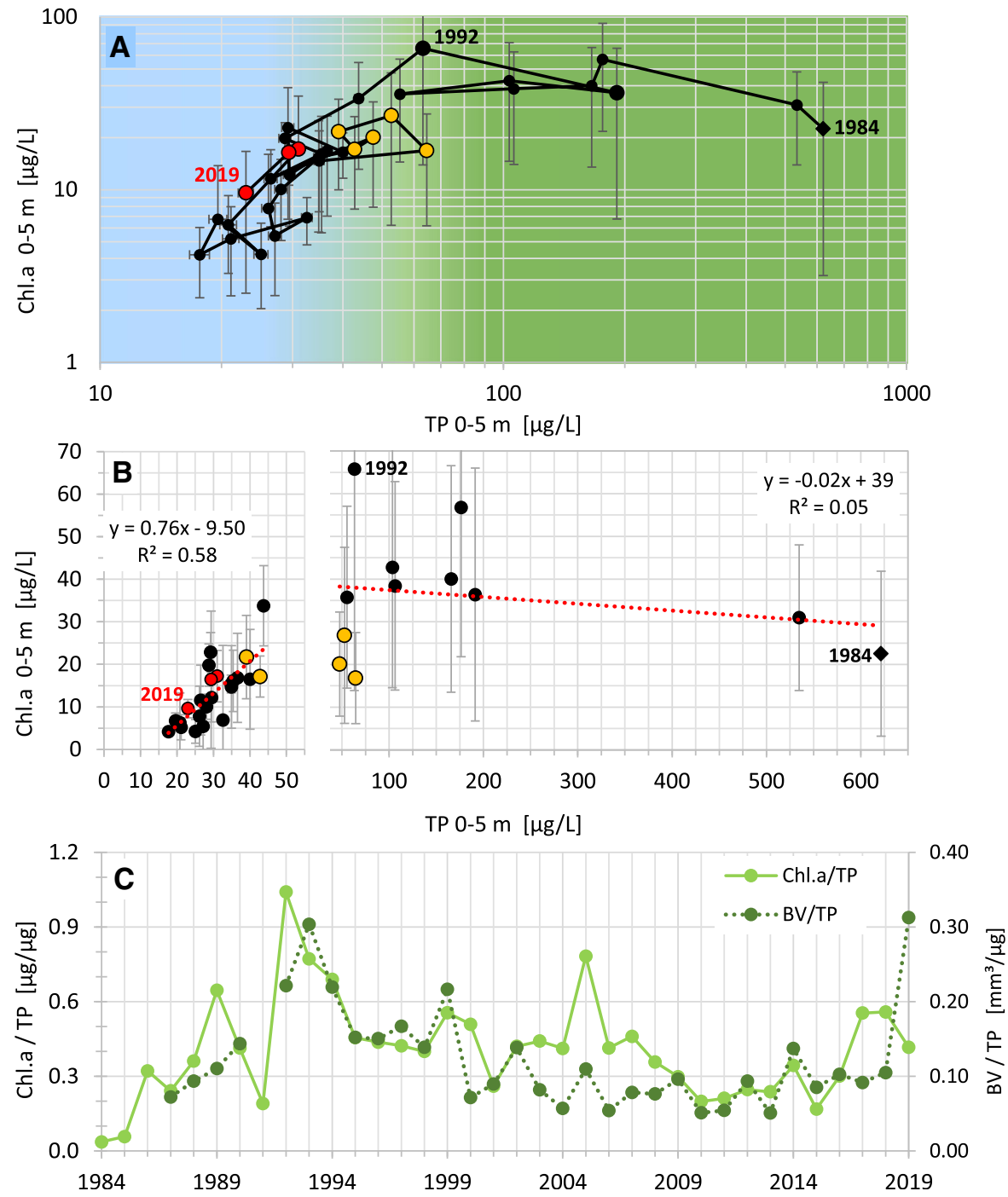

dominance and blooms in 1994 at summer mean TP concentrations of $29 \mu \mathrm{g} / \mathrm{l}$ : in that year cyanobacteria attained a significant population only at the beginning of August (Fig. 6; maximum $2.9 \mathrm{~mm}^{3} / \mathrm{l}$ ). Over the entire time span between 2002 and 2018 in which mean summer epilimnetic TP concentrations were below $30 \mu \mathrm{g} / \mathrm{l}$, cyanobacterial biovolumes above $10 \mathrm{~mm}^{3} / 1$ were no longer observed, and at less than $20 \mu \mathrm{g} / \mathrm{l}$ they remained below $1 \mathrm{~mm}^{3} / 1$ with one exception, i.e. an unusual development of Limnothrix in April which attained $3.7 \mathrm{~mm}^{3} / 1$. From 2007 until 2016, cyanobacterial biovolumes were rarely present in amounts that could be quantified. They did, however, trace the renewed increase of TP concentrations from 2017 to 2019 with a low biovolume of up to $0.3-0.6 \mathrm{~mm}^{3} / 1$.

Microcystis spp. was the dominant cyanobacterial genus throughout most of the study period, sometimes associated with Aphanizomenon and occasionally with transient populations of Dolichospermum. Microcystis biovolumes were highest before 1992, while aerator operation was still weakening thermal stratification. Interestingly, from 1992 to 1994 Planktothrix agardhii transiently became dominant, largely replacing Microcystis. This switch in dominance coincided with more stable stratification beginning in 1992 after more than a decade of artificial mixing through the aerators (Fig. S.2, Supplementary Material). Also, in 1992 and 1993 phytoplankton biomass and consequently 


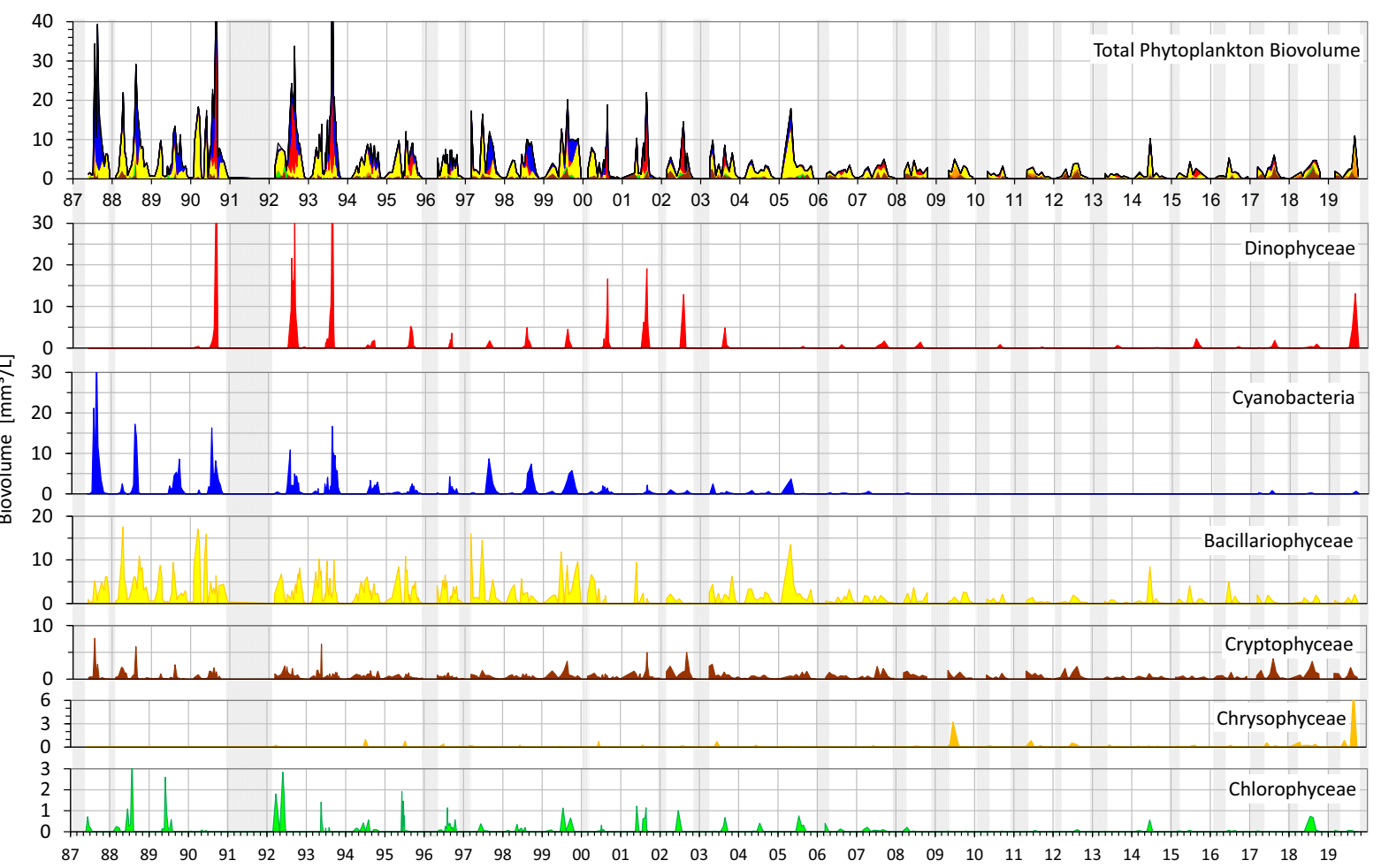

Fig. 6 Total phytoplankton biovolume and that of main groups $\left(\mathrm{mm}^{3} / 1\right)$ over time. Shaded areas show data gaps. Note different scales for Chrysophyceae and Chlorophyceae

Fig. 7 Biovolumes of main phytoplankton groups in 331 depth-integrated epilimnion samples $\left(\mathrm{mm}^{3} / 1\right.$; vertical axes) relative to epilimnetic mean $(0-5 \mathrm{~m})$

concentrations of total phosphorus $(\mu \mathrm{g} / \mathrm{l}$; horizontal axes); open black circles: 1987-2006; solid red circles: 2007-2019; dotted curves envelope maxima. Note different scales for biovolumes
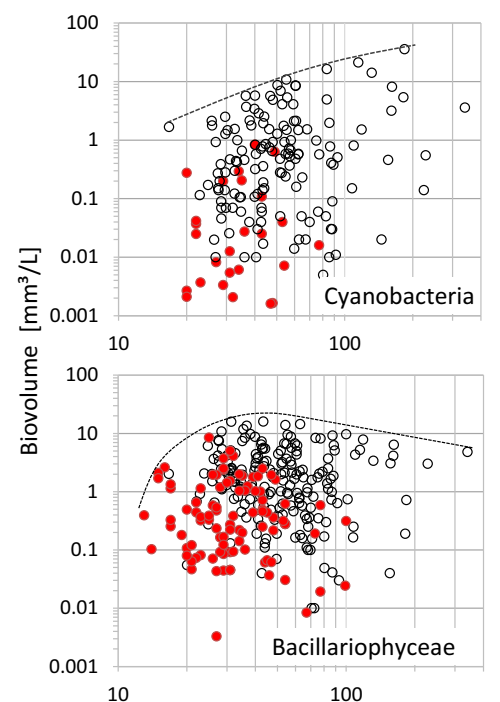
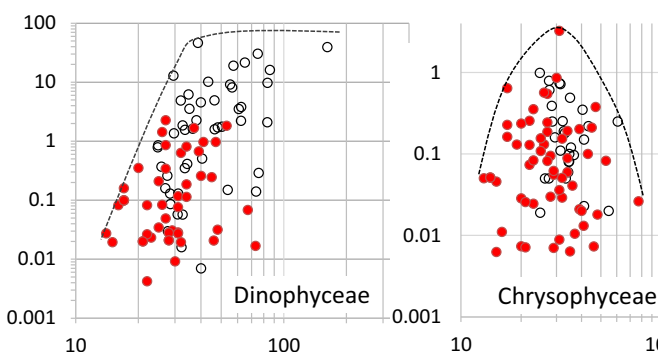

Chrysophyceae

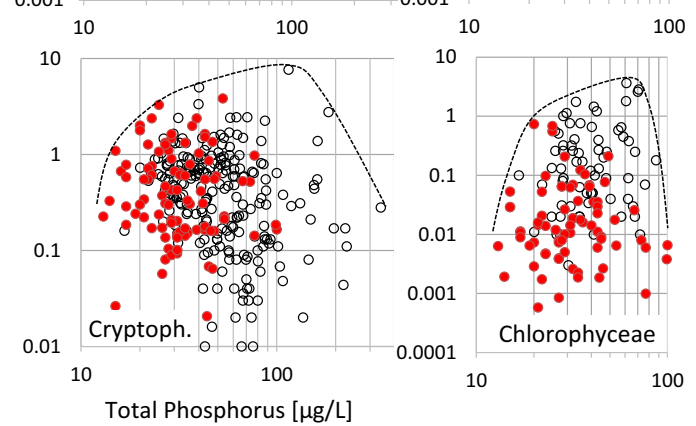

turbidity were yet quite high (at summer mean TP concentrations of 44 and $63 \mu \mathrm{g} / \mathrm{l})$. $P$. agardhii prevailed, albeit at a substantially lower level of biomass in 1994 (when mean summer TP dropped to $29 \mu \mathrm{g} / \mathrm{l}$ ), but dominance switched back to Microcystis in 1995.

During the phase of re-eutrophication from 1997 to 2000 with summer mean epilimnetic TP 
concentrations ranging up to $65 \mu \mathrm{g} / \mathrm{l}$, maxima of cyanobacteria (again dominated by Microcystis) reappeared with biovolumes of up to $6-7 \mathrm{~mm}^{3} / 1$, together with substantial populations of diatoms (Fig. 6). Conspicuously, however, during this 4-5-year phase of "re-eutrophication" they did not attain the biovolumes they had reached at the same TP concentrations before 1994. Figure 7 also highlights that after 2006 in the TP concentration range between 10 and $50 \mu \mathrm{g} / \mathrm{l}$, cyanobacteria no longer attained the biovolumes they had reached at the same TP levels in earlier years.

Dinophyceae (chiefly Ceratium spp. together with minor populations of Peridinium spp.) became relevant in Lake Tegel starting in 1992, i.e. after aeration management had been changed to allow for stable thermal stratification. While quantitative biovolume data are available only since the summer of 1987 , observations from net hauls confirm the absence of Dinophyceae for 1984-1986 (with the exception of two minor findings in 1984; data not shown).

While the absolute biovolumes of dinoflagellates reflect epilimnion TP concentrations (Fig. 7), their share of biomass relative to that of Microcystis relates to the stability of thermal stratification: Chorus \& Schauser (2011) found pronounced dominance of Ceratium in Lake Tegel if the temperature difference between 0 and $11 \mathrm{~m}$ depth amounted to more than $5^{\circ} \mathrm{C}$ and the thermocline was not deeper than $9 \mathrm{~m}$; in contrast, Microcystis developed elevated biovolumes (i.e. $>1 \mathrm{~mm}^{3} / \mathrm{l}$ ) more frequently than Ceratium if the temperature difference between 0 and $11 \mathrm{~m}$ was less than $6^{\circ} \mathrm{C}$ and the thermocline was deeper than $9 \mathrm{~m}$. Thus, while the absolute biomass attained by either of these taxa depends on the TP concentration, the mixing regime appears to determine which of the two can dominate.

In relation to TP the Dinophyceae showed a different pattern than the cyanobacteria (Fig. 7): while at the low TP concentrations since 2006 the latter were no longer present in the phytoplankton in amounts that could be quantified, Dinophyceae remained relevant at TP concentrations between 10 and $20 \mu \mathrm{g} / \mathrm{l}$, and relative to TP there was no difference in the biovolumes they reached attained during the highly eutrophic phase in the early 1990s. Since 2007, at TP concentrations below $20 \mu \mathrm{g} / \mathrm{l}$, Dinophyceae have been contributing quantifiable fractions of the phytoplankton biovolume, and in 2019 they developed a substantial population (Figs. 6 and 7). The envelope curve above the data in Fig. 7 is almost linear up to about $30 \mu \mathrm{g} / \mathrm{l} \mathrm{TP}$, above which their biomass appears to level off. This suggests Lake Tegel to have become a more suitable habitat for dinoflagellates - a shift in species composition that may in part be due to increased transparency of the water in the wake of lower levels of phytoplankton biomass and in part due to consistently more stable stratification.

Cryptophyceae were the group most commonly and almost continuously present in Lake Tegel's phytoplankton and they showed the least pronounced response to restoration. Only their maxima were somewhat lower in most of the years since TP concentrations became limiting in 1994, and maxima later in autumn partially coincided with the return of moderately increased TP concentrations. This modest restoration response in line with expectations derived from their ecology as discussed by Salmaso et al. (2018) who point out that their abundance may be higher "at the lower range of the eutrophication gradient", in part due to mixotrophy. Although not quantified, bacteria have been observed as conspicuously abundant during microscopy of phytoplankton in samples from Lake Tegel, which is not surprising in face of the inflow of treated sewage with a high DOC load (concentrations in Lake Tegel are in the range of 6-10 mg/l; data not shown).

Being excellent food for zooplankton, cryptophytes showed minima in late spring and early summer (Fig. 6), attributable to grazing losses (see below). The shift in stratification stability in 1992 due to the change in aerator operation did not appear to have any impact: although Cryptophyceae are also motile via flagella, they may be less favoured by stable stratification than the dinoflagellates which are much larger and thus more capable of vertical migration.

Bacillariophyceae (diatoms) are the other group that almost always forms populations in Lake Tegel. Their most pronounced response to restoration occurred once TP concentrations declined below $20 \mu \mathrm{g} / \mathrm{l}$ (Fig. 7), while summer maxima began to decline already in 2001 to less than half of those in earlier years (Fig. 6). Moreover, while large pennate or filamentous diatoms typically formed maxima in early spring or even in winter under ice and a second maximum in summer, such spring maxima were no longer observed since 2007 (although in some years since 2008 sampling began only towards the end of April, and thus we cannot exclude some early spring 
maxima to have been missed). While the biomass of diatoms can be limited by the concentrations of silicate if these are below $50 \mu \mathrm{g} / \mathrm{l}$ (Reynolds, 1997), this is not the case in Lake Tegel: silicate concentrations (data not shown) did not drop below this threshold and were usually well above $100 \mu \mathrm{g} / \mathrm{l}$, thus too high to be limiting.

Chrysophyceae were not encountered in Lake Tegel during the lake's eutrophic phase: with a single exception of Dinobryon spp. found in net haul plankton once in 1984 (data not shown) they only appeared once $\mathrm{pH}$ was below 8 , which was the case once TP concentrations remained below $80 \mu \mathrm{g} / \mathrm{l}$. This is most likely attributable to their sensitivity to high $\mathrm{pH}$ at the high rates of photosynthesis through high biomass during the lake's eutrophic phase. Dinobryon spp. occurred regularly since 1994, and Uroglena spp. were sometimes found with minor biovolumes. Chrysophyceae became more relevant, particularly regarding more extended periods of occurrence, since 2009 and their biovolumes show a clear maximum in the TP range of $20 \mu \mathrm{g} / \mathrm{l}$. A high biovolume of Dinobryon $\left(7.5 \mathrm{~mm}^{3} / \mathrm{l}\right)$ was first observed in early September of 2019 (Fig. 7).

Chlorophyceae formed populations in some years with varying species, with Ankyra spp. being the only taxon present in most years at least in small numbers detected in plankton net samples. While the Chlorophyceae maxima increased with TP concentrations up to $60 \mu \mathrm{g} / \mathrm{l}$ (Fig. 7), none of the samples with TP concentrations above $100 \mu \mathrm{g} / \mathrm{l}$ contained quantitatively relevant amounts.

Other taxa found in Lake Tegel include, e.g. Conjugatophyceae (Closterium spp. and Staurastrum spp.) and Euglenophyceae which, however, attained only negligible populations and these only sporadically.

\section{Response of water transparency}

Water transparency in Lake Tegel, determined as Secchi disc readings $\left(\mathrm{z}_{\mathrm{s}}\right)$, strongly reflects phytoplankton biomass (Figs. 4 and 8). During the times of heavy cyanobacterial blooms, Secchi depths recorded during summer since 1974 (data shown only since 1984) frequently amounted to less than $1 \mathrm{~m}$ and sometimes declined to 0.3 or $0.4 \mathrm{~m}$. Even during winter, they rarely exceeded 2.5 and never $3 \mathrm{~m}$, and a spring clearwater phase was recorded only in some of these

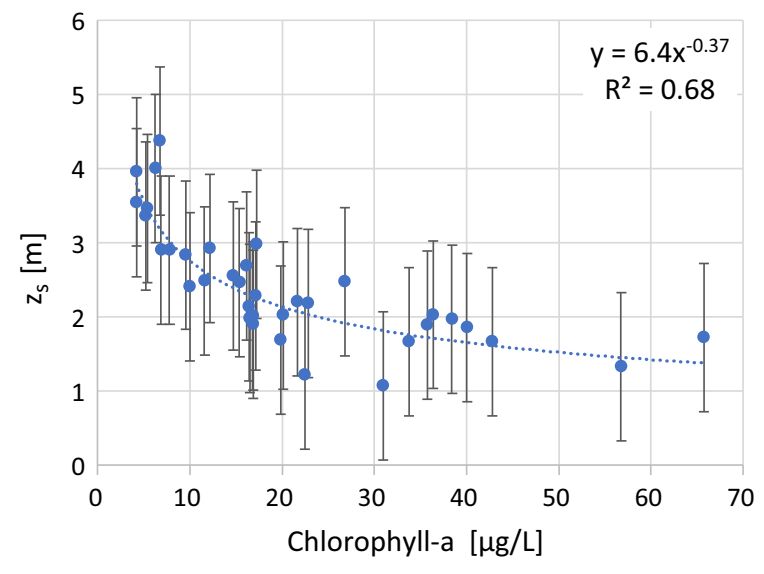

Fig. 8 Summer mean (May-Sept.) Secchi depths relative to the concentration of chlorophyll-a (means 0-5 m)

years, with $\mathrm{z}_{\mathrm{S}}$ in the range of $1-1.6 \mathrm{~m}$ and a rare exception of $3 \mathrm{~m}$ in 1984. Interestingly, transparency started to increase slightly already in 1986, both during the spring clearwater phase and in midsummer, well before both the maximum and the epilimnetic mean concentrations of Chl. ${ }^{1}$ had shown any clear response to reduced TP concentrations. This pattern is consistent throughout the years 1987-1993. While Sas (1989) postulate a deeper distribution of phytoplankton as first response to reduced TP concentrations, for Lake Tegel this explanation is not plausible, as no such changes are visible in the depth distribution of the concentrations of Chl.a (data not shown) and pronounced cyanobacterial blooms remained clearly visible during sampling for several further years.

Transparency increased substantially in 1994, the 10th year after implementation of the PEP, reflecting the absence of a cyanobacterial bloom: While in 1993 during August and September Secchi readings did not exceed $1.3 \mathrm{~m}$, in 1994 they ranged up to $3 \mathrm{~m}$ in late July, with monthly means of 2.4 for August and 2.2 for September. From 1994 to 1996, Secchi depths remained consistently higher, i.e. never less than 1.3 $\mathrm{m}$, reflecting the new situation with cyanobacteria no longer dominating and substantially less phytoplankton biomass. Beginning in 2009 and up to 2016, together with the further decrease in phytoplankton biomass, the Secchi disc data mark the switch to a

\footnotetext{
${ }^{1}$ In the years before 1987, Chl.a concentrations are the only data available as parameter for phytoplankton biomass.
} 
situation with substantially clearer water for more extended periods of time-including summers during which readings of less than $3 \mathrm{~m}$ were the exception. During the 4-5 years of re-eutrophication after 1997 transparency declined somewhat, with summer $z_{s}$ frequently between 1 and $2 \mathrm{~m}$, paralleling the increase in phytoplankton biomass. In contrast, the slight biomass increase after 2017 only affected the minima of $z_{\mathrm{s}}$ which were slightly lower, while maxima above $6 \mathrm{~m}$ continued to be recorded, with winter values even reaching $8 \mathrm{~m}$-an absolute record since decades.

Response of zooplankton to changes in phytoplankton and fish populations

For zooplankton quantitative data are available from 1994 until 2009 (Fig. 9). 1994 was the first year in which phytoplankton biomass decreased in response to restoration, and it decreased further until 1996. Noticeably, the pronounced zooplankton maxima observed during May in 1995 and 1997 were absent in May of 1996. This may be due to the lower phytoplankton biomass in the spring of that year, in which ice cover was massive and lasted until the beginning of April. During the years of re-eutrophication, 1997-2001, zooplankton biomass increased somewhat and then declined substantially in the following years. From 1997 to 2001, when concentrations of TP and phytoplankton biomass increased again (including that of small-sized diatoms susceptible to grazing), so did zooplankton biomass, in 1999 and 2000 particularly that of the copepods. After 2002, zooplankton biomass gradually declined, tracing the decline of phytoplankton, particularly after $2006 / 2007$, with lower levels of biomass of both Cladocera and Copepoda. Food quality for zooplankton, however, remained high, with about $80 \%$ of the phytoplankton consisting of species with diameters of less than $20 \mu \mathrm{m}$.

Among the cladocerans, species composition chiefly consisted Daphnia galeata with some D. hyalina and hybrids of both species. D. cuculata occurred but populations were minor. From 1994 until 1997, Leptodora kindtii attained biomass levels of up to $10 \mathrm{mg} / \mathrm{l}$, Polyphemus sp. were also observed in the samples and Chaoborus were found regularly from 1994 until 1997 with up to means of 12 individuals per litre (data not shown). Leptodora kindtii conspicuously disappeared in 1998, as the re-eutrophication phase progressed, but reappeared for a short period of 3 years from 2002 to 2004. Among the copepods Cyclops kolensis was dominant in spring. Predation by copepods likely kept the population densities of smaller Cladocera (Bosmina longirostris, Eubosmina coregoni thersites) low, i.e. rarely above $2-3 \mathrm{mg} / \mathrm{l}$ of biomass. Likewise, Rotifers rarely contributed more than $1 \mathrm{mg} / \mathrm{l}$ of biomass.

Seasonal patterns show substantial spring maxima of Daphnia, and they are their grazing of the spring populations of small diatoms and cryptomonads is the likely cause of the clearwater phases in May/June (with maxima of $4 \mathrm{~m}$ Secchi depths and more from 1994 on (Fig. 4). Zooplankton biomass regularly showed minima in early summer. Maxima in late summer and autumn consisted particularly of calanoid copepods (Eudiaptomus gracilis) together with smaller amounts of Cladocera and minor biomasses of rotifers (Polyarthra spp., Synchaeta spp.).

Information on fish populations is available for Lake Tegel for some years from the commercial fish yield reported to the local authority, showing substantially lower yields in 1997 and 2002 as compared to 1994-1996 (Fig. 10). Anecdotal evidence supports the data showing reduced yield: local hobby anglers as well as professional fishing enterprises complained about reduced catch, and pike perch were observed to migrate from Lake Tegel into the more turbid waters of the Havel River where these likely encountered a larger supply of their prey, i.e. small fish. A cause for less fish may have been elevated levels of nitrite beginning in the summer of 1995 up to 2001: in $7 \mathrm{~m}$ depth concentrations of nitrite- $\mathrm{N}$ regularly increased during summer and autumn to maxima of $0.1-0.2 \mathrm{mg} /$ 1 (data not shown), i.e. into a range that can be sublethally toxic to fish and trigger their migration. This is supported by anecdotal evidence reported by the fishing enterprises who complained about pronounced losses in 1995 through mortality of several species in fish trap nets positioned in Lake Tegel at $7 \mathrm{~m}$ depth. By 2001 nitrite-N concentrations no longer exceeded $0.04 \mathrm{mg} / \mathrm{l}$, and fish were observed to return to Lake Tegel, particularly cyprinids, perch and pike, albeit not to the previous levels.

The remaining Bosmina coregoni thersithes and $B$. coregoni berolinensis observed in the presence of Leptodora had conspicuously large appendices of their carapax which protect them from predation by invertebrates, and we observed more large-sized, egg- 


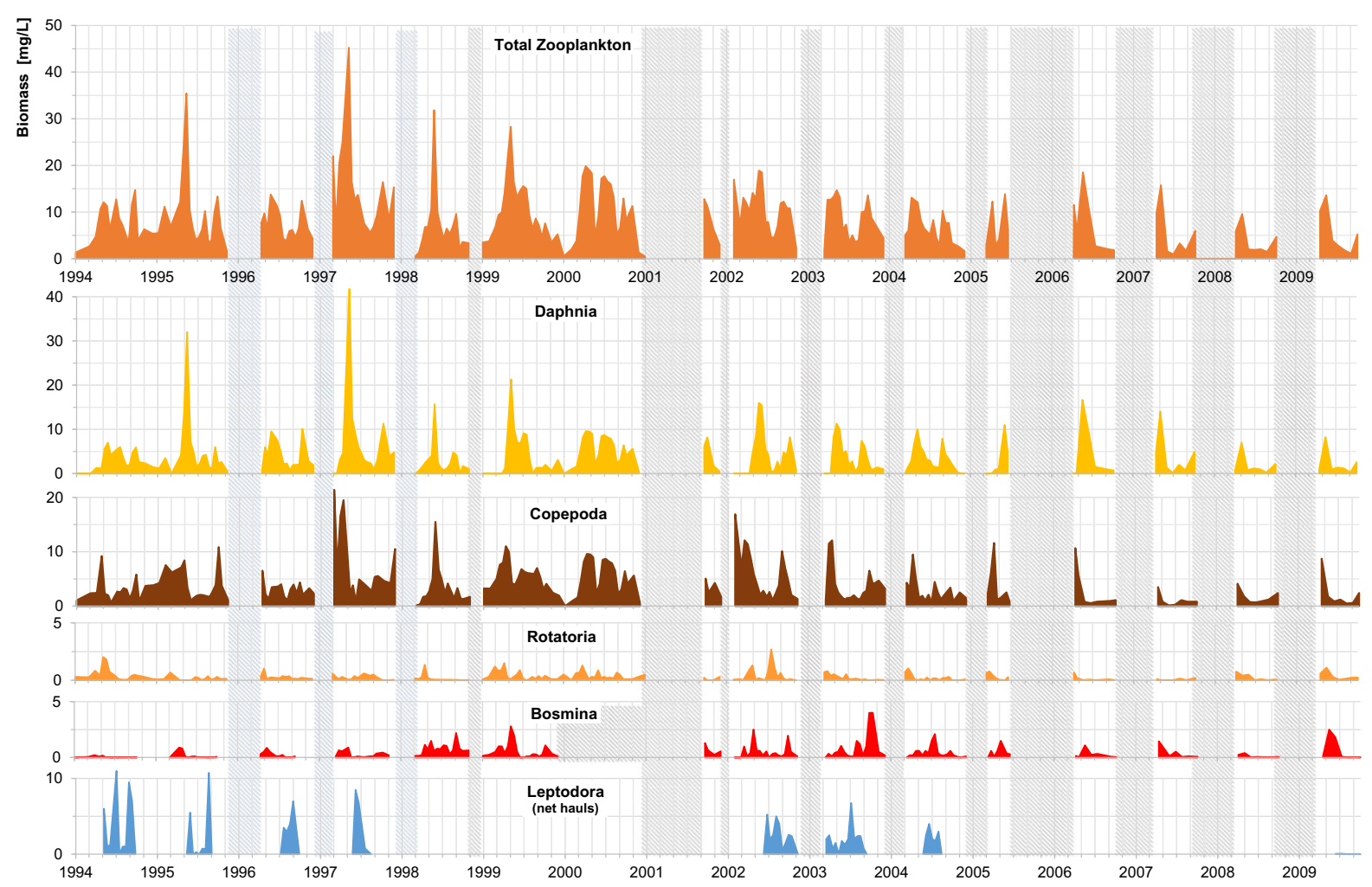

Fig. 9 Zooplankton biomass. Shaded areas indicate data gaps. Note that only Leptodora was sampled with a plankton net and their biomass is not included in the total zooplankton biomass

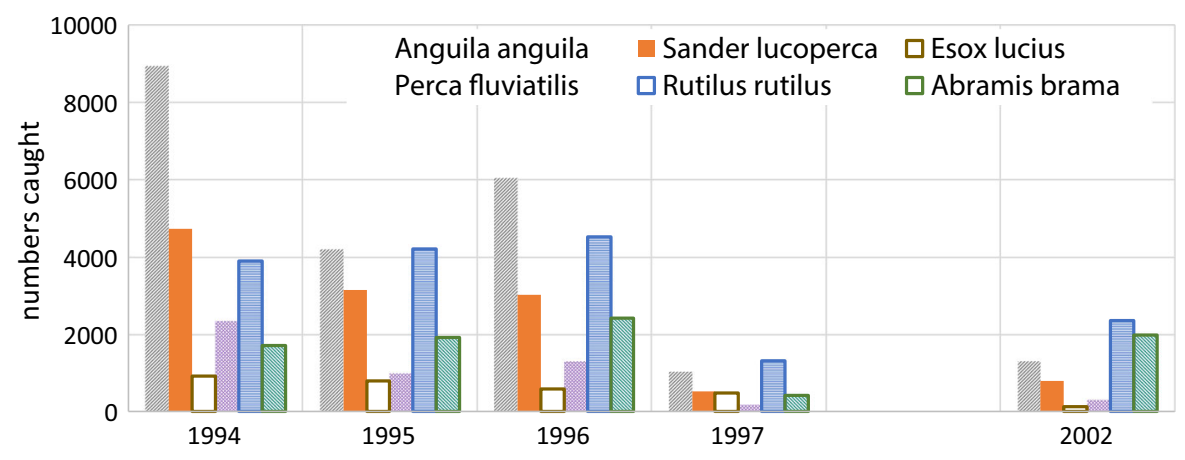

Fig. 10 Decline of commercial fish yield in Lake Tegel (data kindly provided by the Berlin Fisheries authority)

bearing Daphnia galeata which are less susceptible to predation by invertebrates. The larger body size of the cladocerans partially compensates their lower numbers, thus keeping their biomass high although population density declined.

Probably due to the return of the fish populations, Leptodora kindtii was found no longer or only sporadically in very low numbers, thus alleviating the predation pressure on small-sized zooplankton, and among the Daphnia the share of the smaller D. hyalina increased.

Responses of submerged macrophytes and observation of Dreissena

Since 2012, submerged macrophytes have reclaimed Lake Tegel: While survey data for earlier years are lacking, submerged macrophytes are known to have 
Table 3 Maximum depth of vegetation in the transects surveyed in 2007, 2012, 2016 and 2019

\begin{tabular}{|c|c|c|c|c|}
\hline & \multicolumn{4}{|c|}{ Maximum depth of vegetation [m] } \\
\hline Transect & 2007 & 2012 & 2016 & 2019 \\
\hline 1 & 3.1 & 5.5 & 6.2 & 5.0 \\
\hline 2 & 1.4 & 3.6 & 6.5 & 6.2 \\
\hline 3 & 1.7 & 3.4 & 6.0 & 6.0 \\
\hline 4 & 1.7 & 3.5 & 6.3 & 6.1 \\
\hline 5 & 2,2 & $3.4^{*}$ & $3.7^{*}$ & $3^{*}$ \\
\hline 6 & 2.2 & $3.4^{*}$ & $3.8^{*}$ & $2.9^{*}$ \\
\hline 7 & 1.7 & 4.3 & $4.0^{*}$ & $3.7^{*}$ \\
\hline 8 & 3.3 & 5.0 & 7.7 & 8.4 \\
\hline 9 & 2.2 & 3.8 & 8.0 & 6.5 \\
\hline 10 & 3.7 & $2.6^{*}$ & 7.4 & 4.6 \\
\hline 11 & 2.2 & 2.7 & $2.8^{*}$ & 6.1 \\
\hline 12 & 2.5 & $4.3^{*}$ & 6.2 & 3.5 \\
\hline 13 & 2.9 & $4.0^{*}$ & 4.0 & 6.4 \\
\hline 14 & 2.1 & 3.6 & 6.4 & 4,8 \\
\hline 15 & 2.8 & 4.7 & 6.3 & $4.3^{*}$ \\
\hline 16 & 0 & 4.7 & $4.6^{*}$ & $5.9 \pm 0.13$ \\
\hline Mean \pm SD & $2.2 \pm 0.87$ & $4.1 \pm 0.83$ & $6.4 \pm 0.11$ & mesotrophic \\
\hline Trophic level & Highly eutrophic & eutrophic & mesotrophic & \\
\hline & (close to & (close to & & \\
\hline
\end{tabular}

*Lower boundary not attained (data not included in the mean)

Cells shaded grey: assessment by diving; data for 2007 from Hilt et al. (2010b)

largely been absent during the lake's hypertrophic phase. By 2016, they were present in all transects, in 2016 down to $8 \mathrm{~m}$ depth. In 2016, their mean maximum depths amounted to $6.4 \mathrm{~m}$ (Table 3) and in 2019 to $5.9 \mathrm{~m}$. Figure 4 shows these results compared to those for 2012 as well as those for 2007 and 1988 by Hilt et al. (2010b). The results for 2016 and 2019 exceed the theoretical maximum depth limit that Hilt et al. (2010b) assumed earlier by about a factor of 2. This is a significant improvement as compared to the earlier years in which the means of the maximum depth covered by macrophytes had reached only down to $4.1 \mathrm{~m}$ in 2012, $2.2 \mathrm{~m}$ in 2007 and to $0.5 \mathrm{~m}$ in 1988.

Species composition also showed a pronounced development towards an improved ecological quality: While in 2007 the large angiosperms Stuckenia pectinata (Potamogeton pectinatus) and Myriophyllum spicatum clearly dominated, by 2016 Fontinalis antipyretica had become the dominant species, occurring more than twice as frequently as in 2012. Ceratophyllum demersum, Myriophyllum verticillatum, and Ranunculus circinatus also increased, whereas stands of Ceratophyllum submersum and Myriophyllum spicatum decreased. In some shallow bays, Nuphar lutea and Nymphaea alba covered extended surface areas. Chara contraria and Nitellopsis obtusa have begun to spread in Lake Tegel, but altogether Characeae occurred only in minor amounts. For macrophytes, numerous authors do not expect full reversibility to the pre-eutrophication species composition due to their previous widespread disappearance having led to a lack of seeds and propagules in the 
Table 4 Time scales for the restoration response of Lake Tegel—at a reduction of the load from the main tributary by a factor of 40 exchanging the lake's water volume 3-4 times per year

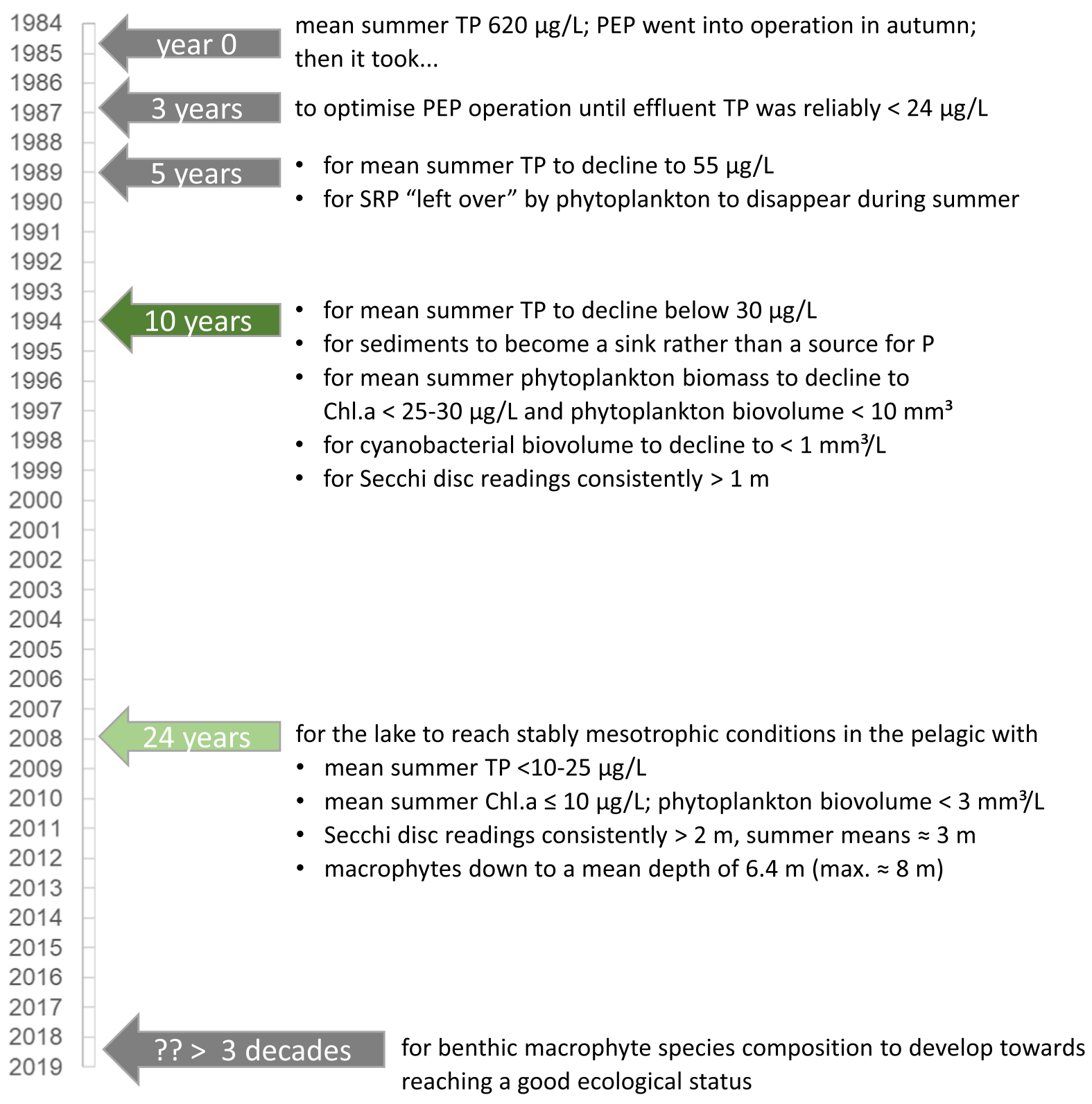

Arrows shaded green for 1994 and 2008 indicate breakpoints in the development of phytoplankton biomass

lakes' vicinity (Baastrup-Spohr et al., 2017 and literature therein).

During the macrophyte surveys, Dreissena spp. (chiefly the invasive Quagga mussel, i.e. D. rostriformis bugensis but also some D. polymorpha which have been known to occur in large numbers since decades) were observed in all transects, often down to $8 \mathrm{~m}$ depth, with these molluscs forming dense stands covering up to $100 \%$ of some sediment areas. 


\section{Discussion}

Restoration of Lake Tegel was unusually clear-cut in four ways: (1) the lake had been extremely hypertrophic for 3-4 decades; (2) the TP load carried by the main tributary was sharply reduced by a factor of about 40; (3) this reduction occurred suddenly within 1-2 years and (4) the lake's water volume was flushed $3-4$ times per year with water containing only $\approx 20$ $\mu \mathrm{g} / \mathrm{l}$ of TP. These unusually clear-cut conditions provide a rare opportunity to explore the time spans necessary for a massive load reduction to cascade through the trophic levels. Also, a 5-year intermezzo during which the exchange with low-P water was reduced to about 1.5-2 times per year provided the opportunity to study the role of the residence time for trophic recovery. The central objective of this analysis of 35 years of data was to find out how many years it takes for changes in key ecosystem components to become apparent and to which extent ecosystem components show resilience to re-oligotrophication.

It took 10 years for TP concentrations to decline to levels clearly limiting phytoplankton biomass: by 1994, the sediments had become a sink rather than a source for $\mathrm{P}$, and cyanobacteria had become subdominant in the phytoplankton (Table 4). This phytoplankton response occurred suddenly, with a biomass reduction by a factor of 2 from 1 year to the next. The 5-year trial-and-error approach of experimenting with a lower hydraulic load from the PEP around the turn of the millennium clearly interrupted trophic recovery, causing a renewed increase of TP concentrations, with the biomass of both phytoplankton and zooplankton following suite, but after this phase of increasing TP concentrations TP continued to decline. Phytoplankton biomass showed a second breakpoint between 2007 and 2008, once summer mean TP concentrations were usually well below $30 \mu \mathrm{g} / \mathrm{l}$. Following the trophic state criteria proposed by Vollenweider \& Kerekes (1982), Lake Tegel reached a clearly mesotrophic status by about 2004, i.e. 24 years after load reduction.

Without the 5-year intermezzo of experimenting with a reduced inflow of low-P water from the PEP, trophic recovery to this state would have taken roughly 2 decades. From 2008 until 2016, further oligotrophication progressed slowly and gradually, and as TP concentrations in the water continued to decline, transparency and macrophyte cover increased substantially. After 3 decades, macrophytes have recolonised substantial parts of the lake bottom, and their species composition is still developing towards a good ecological status.

Since 2017, renewed reduction of PEP operation again led to influx of more untreated Havel River water carrying a higher TP load, and this has caused a second phase of increased of TP concentrations (although less pronounced than in 1997-2001). Phytoplankton biomass followed immediately, as did decreasing Secchi depths, both with a surprisingly pronounced response relative to the rather modest increase of TP (Fig. 11). This might or might not impair further macrophyte re-colonisation as, relative to the concentrations of Chl.a, the decline of Secchi depths was pronounced. At the beginning of 2020, it is uncertain whether a prolonged reduced PEP operation may risk compromising the recovery process of the benthic biota. While it took 20-25 years for the pelagic zone to reach the mesotrophic conditions targeted by restoration, benthic community structure-i.e. species composition-is still catching up.

These results confirm the initial assumption when planning the restoration of Lake Tegel that in face of the pronounced load reduction and rather high turnover rate with low-P water of 3-4 times per year, no additional measures beyond the load reduction would be necessary to shift the lake from a hypertrophic to a mesotrophic state. Once the TP concentrations were in the range limiting phytoplankton biomass, this responded immediately, and zooplankton biomass responded to the decrease of phytoplankton biomass. Overall, resilience phenomena were negligible, but the response of most ecosystem components to trophic change was discontinuous, showing thresholds.

Further sources of phosphorus and the relevance of the internal load from the sediments

Had the load from the PEP been the only source of TP to Lake Tegel, the turnover rate of 3-4 times per year would have diluted the concentration of almost $700 \mathrm{mg} / \mathrm{l} \mathrm{TP}$ in 1984 down to $30 \mu \mathrm{g} / \mathrm{l}$ or less already by 1989 (Chorus \& Schauser 2011). In practice, the lake took twice as long to reach this concentration, and the pronounced TP peaks in autumn (Fig. 2) show that further loads occurred. Candidate sources are internal loading from the sediment as well as further external loads, particularly from the Havel River. The similar 


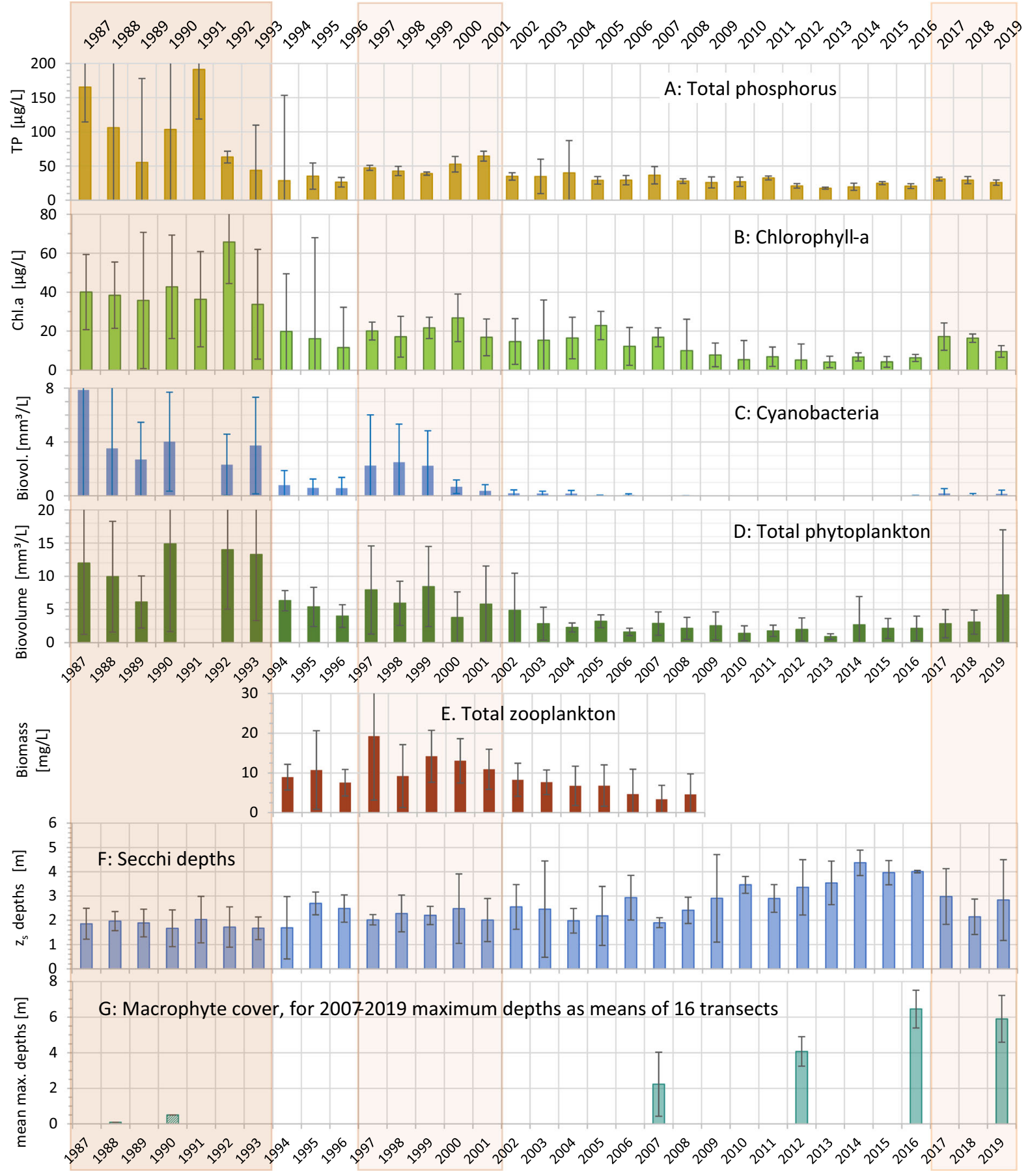

Fig. 11 Synopsis of restoration responses. All bars in panels A-F shows means for May-September and from 0 to $5 \mathrm{~m}$ depth. Macrophyte cover in panel $\mathbf{F}$ shows means over transects (data for 1988 and 2007 are from Hilt et al. (2010b). Vertical brown

seasonality of $\mathrm{P}$ concentrations in the Havel River and in Lake Tegel indicates that a relevant fraction of the $\mathrm{P}$ shading indicates eutrophic phases discussed in the text, i.e. hypertrophic from 1987 to 1993 and re-eutrophication in 1997-2001 and 2017-2019

dynamics of Lake Tegel is controlled by the river. The hydraulic load from the PEP is measured, but due to 
the two broad connections of the lake to the river the hydraulic load from the river cannot be measured. However, it can be estimated: Modelling approaches have shown that the import of river water depends strongly both on the discharge of the PEP and on the meteorological situation (Schauser \& Chorus, 2007; Schimmelpfennig et al., 2012). These estimates arrive at an external load from the river between 25 and $70 \mathrm{t}$ per year (Schauser \& Chorus 2009; Schimmelpfenning et al., 2016), resulting in a contribution of up to $80 \%$ of the external P load. Direct intrusion of Havel River water at the lake's south-western end thus proved to be a significant source of TP loads to the lake.

This is important for the assessment of the source of $\mathrm{P}$ accumulated in the hypolimnion: a large fraction of the phosphorus from the Havel River enters the lake incorporated into the phytoplankton biomass that develops in the river, while later during summer the river water also imported soluble reactive phosphorus detected in the lake samples between the southwestern islands near the river but not in those from the main basin where since $1989 \mathrm{P}$ was incorporated into biomass or seston. External and internal biomass settles to the lake bottom in the form of-e.g. diatoms, zooplankton faeces or detritus, and Schauser et al. (2006b) identified mineralisation of recently settled organic material as the key process releasing $\mathrm{P}$ from the sediments. Thus, while the sediments release some of the historic legacy $\mathrm{P}$, intrusion of river water is the more relevant source of $\mathrm{P}$ accumulating in the hypolimnion. This conclusion is supported by the results of the analysis of $\mathrm{P}$ pools in the upper sediment layers of the deepest area: these show little change of the mobile P pool between $1996\left(2.2 \mathrm{~g} / \mathrm{m}^{2}\right)$ and 2003 $\left(3.6 \mathrm{~g} / \mathrm{m}^{2}\right)$ (Schauser et al., 2006b). This pool is too small to explain the release rates of $4-6 \mathrm{mg} \mathrm{P} / \mathrm{m}^{2} \mathrm{~d}$ observed during summer: related to the hypolimnetic area $(>8 \mathrm{~m})$ the potentially mobile $\mathrm{P}$ pool ranged between 3.2 and 5.3 tons and thus is one order magnitude lower than the annual external $\mathrm{P}$ load. This finding supports the results of the model by Schauser \& Chorus (2009) which indicates that the sediments were a net source for phosphorus only in the few years immediately after the PEP went into operation, i.e. up to 1993 .

A further result showing a minor role of redoxsensitive release of legacy $\mathrm{P}$ from the sediment is that (quite in contrast to one key argument for continuing hypolimnetic aeration voiced in the mid-1980s) legacy $P$ had no significant effect on the long-term trend of the $P$ level in the water of Lake Tegel. Schauser et al. (2006b) showed that $P$ release is more tightly coupled to temperature than to redox conditions, suggesting that up to 1989 aeration, operated to keep the sediments oxidised, more likely enhanced $\mathrm{P}$ release than suppressing it (through increasing temperature at the sediment/water interface and thus mineralisation). Both the sediment core results and the results of Schauser et al. (2006b, 2007) suggest some relevance of redox-sensitive release during a few weeks in summer in the hypolimnion. Lab experiments with sediment cores from Lake Tegel have shown that the presence of molecular or nitrate bound oxygen increases the maximum capacity of redox-controlled $\mathrm{P}$ by about $1.45 \mathrm{~g} \mathrm{P} / \mathrm{m}^{2} \quad(=2.1 \mathrm{t}$ per area $>8 \mathrm{~m}$; Kleeberg et al., 2012; Senate 2017). We conclude that the sediments of Lake Tegel contain sufficient iron for forming of the mineral vivianite which is not influenced by the availability of oxygen in the overlying water. Thus, relative to the external load, options for controlling the $\mathrm{P}$ balance of the lake by oxygen and nitrate are quite limited. A comprehensive study in the upper Havel River confirms that nitrate cannot diminish $\mathrm{P}$ release if organic matter mineralisation is the dominant $\mathrm{P}$ mobilisation process (Grüneberg et al., 2015).

The results for the phosphorus deposition rates in Lake Tegel (Table 2) strongly indicate that the reduced production of biomass in the wake of reduced eutrophication enhances the retention of $\mathrm{P}$ in the sediment by promoting the formation of redox stable vivianite: primary productivity can significantly change the geochemical conditions for $\mathrm{P}$ binding in the sediment. High molar S:Fe ratios reduce the mobility of iron and ability to bind phosphorus in the water and the sediment (Gächter \& Müller, 2003; Rothe et al., 2015): the higher the productivity, the higher the $\mathrm{S}: \mathrm{Fe}$ ratio in the sediments due to higher rates of microbial sulphate reduction and higher S supply from sedimented detritus. At lower S:Fe ratios (a consequence of lower productivity), the iron-phosphorus mineral vivianite can form under reducing conditions (Rothe et al., 2015), and this may significantly contribute to permanently binding $\mathrm{P}$ in the sediment. A similar feedback mechanism is described for the downstream system of the lower Havel River (Rothe et al., 2015). 
Thus, relative to the external load, $\mathrm{P}$ release from legacy sources in sediments of Lake Tegel proved to be of minor relevance and did not cause resilience in the response of concentrations in the lake to reduction of the external load. Rather, concentrations respond quite directly to changes in the external load, and this strongly depends on the residence time: the experience from the years with lower PEP discharge show that reduced throughflow of low-P water from the PEP increases intrusion of P-rich Havel River water; vice versa, maintaining a PEP effluent in the range of $3 \mathrm{~m}^{3} / \mathrm{s}$ is a key measure to reduce this source of TPunless future measures in the Havel catchment succeed in further reducing TP concentrations in this river. ${ }^{2}$ Contrary to resilience, $\mathrm{P}$ retention in the sediments through vivianite formation is even likely to increase disproportionately in the course of re-oligotrophication. Results for this ecosystem component confirm our first hypothesis, i.e. that restoration success required substantial load reduction, but no further measures addressing $\mathrm{P}$ release from the sediments.

Responses of Biota to the reduction of TP concentrations

Lake Tegel's first biological restoration response was the abrupt decline of total phytoplankton biomass in 1994, 10 years after the PEP began operating and once TP declined below a summer mean of $45 \mu \mathrm{g} / \mathrm{l}$. This biomass decline to less than half of the level in the previous year was clearly linked to a shift in species dominance: in 1994 the biomass of cyanobacteria amounted to less than one-third of that in previous years: they now contributed only $18 \%$ of the total phytoplankton's mean summer biovolume, and pronounced surface blooms were no longer apparent. As we can exclude nitrogen, above this TP level the resource most likely limiting further phytoplankton biomass was underwater light availability, influenced by mixing depths in consequence of weather conditions.

For total phytoplankton, this result is below the threshold proposed for phytoplankton biomass by

\footnotetext{
${ }^{2}$ Regarding the impact of water from Lake Tegel on the Havel River, even with P exported from Lake Tegel's sediment, the water leaving the lake to the river dilutes rather than enriches the TP concentrations there (see Fig. S 6 in the Supplementary Material for data on TP concentrations in this river).
}

Phillips et al. (2008) as well as by Carvalho et al. (2013) who analysed data from $>1000$ and $>800$ European lakes, respectively. These authors both found a rather linear relationship of concentrations of Chl.a to those of total phosphorus up to $100 \mu \mathrm{g} / \mathrm{TP}$, above which the data points level off. While such data include a variety of lakes of different total or epilimnion mixing depths, Fastner et al. (2016) compared restoration responses of Lake Tegel to those of 7 other lakes (i.e. Lakes Washington, Constance, Geneva, Maggiore, Onondaga, Balaton and Schlachtensee) and showed that where such turning points were observed, they varied between waterbodies: at higher TP concentrations the shallower lakes attained higher levels of Chl.a at a given TP concentration than those in which deeper mixing carries phytoplankton into light-limited zones for part of the time. Not all of the 8 lakes in that study showed a clear threshold of TP concentrations for a decrease of phytoplankton biomass because during the eutrophic phase of some of them, maximum TP concentrations had not reached levels above such a threshold. However, where their phytoplankton biomass did reach a turning point, mixing depth was one key factor determining the threshold TP concentration: in large deep Lake Constance, with an epilimnion mixed down to $20 \mathrm{~m}$ and more, the threshold for TP of 10-20 $\mu \mathrm{g} / \mathrm{l}$ (mean from May to October) was much lower than in Lake Tegel (with mixing typically down to $7-8 \mathrm{~m}$ by July), and the small Schlachtensee with a thermocline at 3-4 m showed a threshold already at a seasonal mean of $40 \mu \mathrm{g} / \mathrm{l} \mathrm{TP}$. Such differences can be explained with more pronounced light limitation in waterbodies with deeper mixing.

Phytoplankton switching from cyanobacterial blooms to dominance of eukaryotic algae

Several studies addressed TP thresholds specifically for cyanobacterial dominance and blooms, i.e. Carvalho et al. (2013) with > 800 European lakes, Vuorio et al. (2019, this volume) with almost 7000 samples from $>1300$ lakes in Finland, and Chorus \& Niesel (2011) with 672 samples from 210 European lakes. Both Carvalho et al. (2013) and Vuorio et al. (2019) observed cyanobacterial biomass to increase with TP up to approximately $100 \mu \mathrm{g} / \mathrm{l}$ of $\mathrm{TP}$, above which biovolumes level off. In Lake Tegel, maximum summer mean biovolumes of cyanobacteria levelled 
off at less than half of this threshold (Fig. 7). However, the data evaluated both by Carvalho et al. (2003) and by Vuria et al. (2019) include shallow lakes in which, as discussed above, light limitation sets in only at higher biomass concentrations, enabling a higher standing stock not only of total phytoplankton biomass but in particular of cyanobacteria. All three studies, i.e. also Chorus \& Niesel (2011), found cyanobacteria to be quantitatively irrelevant at TP concentrations below 10-20 $\mu \mathrm{g} / \mathrm{l}$, while in Lake Tegel they became irrelevant at 20-30 $\mu \mathrm{g} / \mathrm{l} \mathrm{TP}$; however, Vuorio et al. (2019) differentiate by taxa and found thresholds around $20 \mu \mathrm{g} / \mathrm{l}$ at which both Microcystis and Planktothrix were irrelevant.

In Lake Tegel, the decrease of cyanobacterial biomass in 1994 was very abrupt, likely due both to specific shifts in conditions in the lake and traits of Planktothrix agardhii which dominated the cyanobacteria from 1992 to 1994: Regarding conditions, the summer of 1992, when P. agardhii first appeared, was the first year with pronounced stable thermal stratification (due to reduced aerator operation) and a thermocline at 6-7 m (Fig. S.2). The summer of 1993, during which this species reached a maximum (data not shown), was unusually cool, with deeper mixing of the epilimnion by $1-2 \mathrm{~m}$; thus cells entrained in epilimnetic mixing spent more time in darker depths. Regarding traits, Reynolds et al. (2002) place Planktothrix agardhii in the assemblage S1 whose typical habitat is turbid mixed layers under highly light deficient conditions, and in a darker underwater light climate Planktothrix agardhii can outcompete other phytoplankton. Scheffer et al. (1997) investigated the role of "shade" for the dominance of Oscillatoriales, particularly P. agardhii, in shallow lakes. Applying their approach to the Lake Tegel data for the summer of 1992, when $P$. agardhii first appeared, shows that with a thermocline at 6-8 m during July and early August, Secchi depth transparencies of only 1.2 to 1.6 metres and Chl.a concentrations of $25-100 \mu \mathrm{g} / \mathrm{l}$, the measure for "shade" sensu Scheffer et al. (1997; i.e. an index calculated from the vertical light extinction coefficient and mixing depth) amounts to 11-20. This places Lake Tegel in the upper range of the relative abundance found by these authors for Oscillatoriales in relation to the underwater light conditions.

In contrast, the summers of 1994 and 1995 was unusually warm and sunny, leading to a more shallow and stable thermal stratification Together with half as much biomass and higher Secchi disc readings (Fig. 4) the light climate of the shallower epilimnion in 1994 and 1995 was less favourable for P. agardhii. A similar pattern was observed for Schlachtensee (Fastner et al., 2016; Chorus \& Schlag, 1993) in which cyanobacteria were also dominated by $P$. agardhii. Thus, the specific habitat features of $P$. agardhii may explain the abruptness of the decline of cyanobacteria in Lake Tegel - and the somewhat higher TP levels at which it occurred as compared to the 10-20 $\mu \mathrm{g} / \mathrm{l}$ found in the three meta-analyses discussed above. The decline of $P$. agardhii in 1994 and 1995 is in line with the results of Scheffer et al. (1997) who propose that lakes may switch between years with dominance of Oscillatoriales (during summer frequently Planktothrix agardhii) and an alternative stable state with dominance of other phytoplankton taxa, depending on light conditions and with a feedback loop: Once these filamentous cyanobacteria have multiplied to a biomass density that renders conditions very turbid, this stabilises their dominance, particularly as their loss rates through grazing and sedimentation are low. As illustrated in Fig. 12, if $\mathrm{P}$ limitation succeeds in sufficiently reducing biomass so that more underwater light is available, other phytoplankton species can outcompete $P$. agardhii. If these are species with higher loss rates, this will further stabilise higher transparency, acting against a renewed increase of $P$. agardhii.

The high biovolumes observed for Microcystis up to 1990 , while thermal stratification was weak, appear to contrast with the placement of this taxon by Reynolds et al. (2002) in the functional group LM, which is characterised (among other criteria) by sensitivity to mixing and poor stratification. However, Mantzouki et al. (2016) emphasise that especially large colonies of Microcystis have a high flotation velocity (up to $12 \mathrm{~m}$ within $2 \mathrm{~h}$ ). During the late 1980s, both Microcystis and Aphanizomenon formed large colonies, and during sampling we observed the former sometimes agglomerating to golf-ball-sized globules. This suggests a capability for flotation even under fairly turbulent conditions.

During the two phases of re-eutrophication, in which TP concentrations increased again, phytoplankton biomass did also. However, in 1997-2001 the concentrations of Chl.a and biovolume did not reach the levels that the TP concentrations would have 


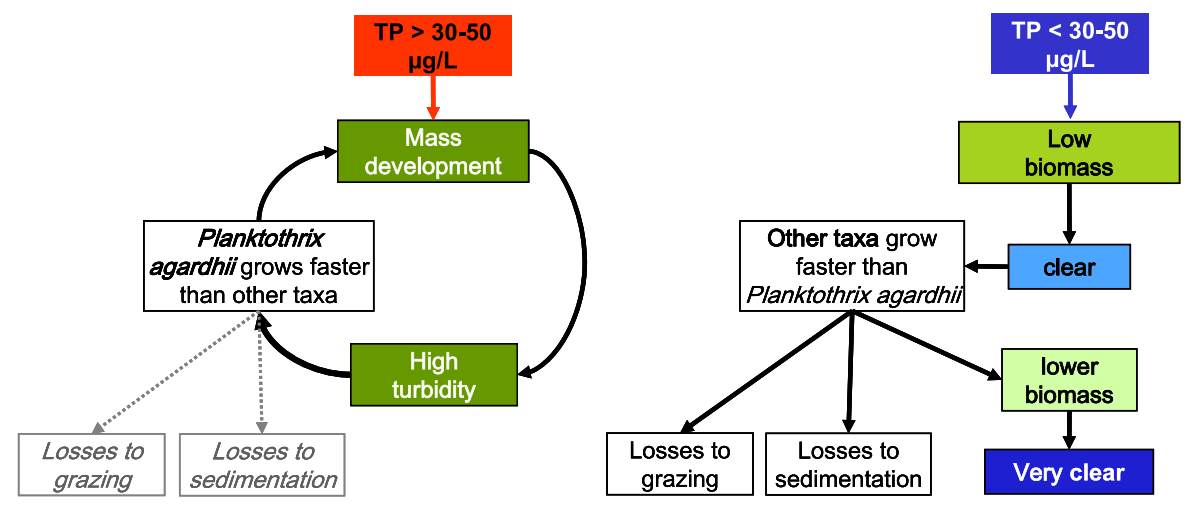

Fig. 12 Conceptual diagram of (left) positive feedback loop stabilising favourable conditions for Planktothrix agardhii until (right) it is disrupted by P limitation of phytoplankton biomass (adapted from Chorus \& Schauser 2011)

supported (Fig. 5) and that had occurred at the same TP concentrations in previous years (Fig. 6). In previous years, at this level of TP, Microcystis had dominated and had achieved significantly higher levels of biomass (Fig. 6), but in 1997-2001 it did not. A possible explanation could be is a significantly lower inoculation success during its springtime habitat shift. Microcystis is meroplanktonic: it overwinters on/in the sediments and reinvades the pelagic during the following spring (Topachevskiy et al. 1969; Preston et al., 1980; Reynolds et al., 1981; Brunberg \& Blomqvist 2003). In Quitzdorf Reservoir, the fraction of this overwintering benthic population that could re-invade the pelagic and form a spring inoculum was very small (Ihle et al. 2005), and a large benthic overwintering stock-formed from a sufficiently large summer population — can be vital for the survival of the spring inoculum. Model studies by Verspagen et al. (2005) showed that in the large Lake Volkerak, the Netherlands, the absence of benthic recruitment could reduce the summer bloom by about $50 \%$. Since Microcystis does not overwinter in the water column, benthic recruitment in spring might play a significant role in forming the inoculum for pelagic growth in Lake Tegel. It is therefore conceivable that after 3 years with considerably lower population densities of Microcystis, the recruitment process from the sediment in spring was less effective due to the absence of heavy summer blooms which ensure a sufficient benthic stock for overwintering and the successful re-establishment of a potent pelagic population.
Zooplankton and the role of grazing

Zooplankton biomass followed the development of phytoplankton biovolume over time quite closely: Summer means of total zooplankton biomass reflect the increase of phytoplankton biovolume from 1997 to 2001 as well as its subsequent decrease (Fig. 11). Summer means of both parameters correlate with an $\mathrm{R}^{2}$ of 0.67 and a slope of 1.6 for the years 1994-2009, and the biomass of Daphnia decreased more steeply with that of phytoplankton than did the biomass of Copepoda (Fig. S.9 in the supplementary material). This is surprising as in the course of trophic recovery well-edible plankton algae decreased less strongly than the poorly edible cyanobacteria and dinoflagellates, i.e. after the regime shift in 1994, small diatoms, Chrysophyceae and Cryptophyceae dominated. These have higher rates of turnover, i.e. higher loss rates due to grazing but also higher growth rates, thus potentially effectively sustaining filter-feeders. The pronounced reduction of zooplankton biomass thus points to some relevance of shifts in predation pressure by fish and macro-invertebrates. Fish scarcely predate upon smaller cladocerans (Bosmina and small Daphnia), but large invertebrates do. Thus, predation by Leptodora may have been the cause of the rather low biomass of these small species in the mid-1990s and for rotifers also in the early 2000s. For earlier years with hypertrophic conditions, Ripl et al. (1993) also reported predation pressure by large invertebrates as relevant.

However, while the shifts observed between zooplankton taxa might have contributed some finetuning of the restoration response, this was not 
decisive. Rather, the immediate phytoplankton response to changes in TP concentrations as well as the immediate zooplankton response to changes in phytoplankton biomass show that in Lake Tegel bottom-up control was the overriding determinant for the levels that biomass can attain-and in consequence for the success of restoration. This is not surprising given the pronounced reduction of TP loads and in-lake concentrations.

\section{Benthic biota and turbidity}

The return of a pronounced macrophyte cover in Lake Tegel contributes to stabilising mesotrophic conditions via the well-known mechanism that Scheffer (1989) described for shallow lakes as alternative stable state. For Scharmützelsee, a larger lake near Berlin, also thermally stratified but with large shallow areas, Hilt et al. (2010a) propose macrophyte recolonization to be both a cause and a consequence of a switch to the mesotrophic state attained by 2004 . These authors conclude that for stratified lakes with a considerable macrophyte cover feedback mechanisms between transparency and macrophyte cover originally postulated for shallow lakes may also apply. For Lake Tegel, the competition of macrophytes with phytoplankton for phosphorus may be particularly effective due to the pronounced dominance of the perennial Fontinalis antipyretica: although clumps may detach and die when transported to the beach, they do not decompose and mineralise to same extent as seasonally occurring macrophytes. The substantial macrophyte cover is also likely to support the function of the sediments as sink rather than source for phosphorus by protecting the surface against resuspension and by trapping settled material (Barko \& James, 1998). Further mechanisms such as the excretion of allelopathic substances may contribute to suppressing phytoplankton (Hupfer \& Hilt, 2008).

Both with respect to maximum depth of coverage and species composition, already by 2016 the macrophyte populations in Lake Tegel had attained a much better condition than Hilt et al. (2010b) had expected 10 years earlier in the light of a likely lack of propagules in the species-poor eutrophic to hypertrophic lakes and rivers in the lake's vicinity. Qualitatively, with respect to the target of reaching a good ecological status, the findings of the surveys in 2016 and 2019 show an improvement from an ecological status classified as "unsatisfactory" in 2007 to a "moderate" status in $2016 .{ }^{3}$ The maximum depth of macrophyte occurrence down to 3-6 m corresponds to mesotrophic conditions following Succow \& Kopp (1985). Lake Tegel is now well in line with the water quality targets that Polkane et al. (2014) proposed for macrophyte coverage on the basis of an analysis of data on the maximum depth of macrophyte coverage in relation to the concentrations of Chl.a from 539 moderately deep (3-15 m) lowland lakes: For this lake type they found a Chl.a threshold of 10-11 $\mu \mathrm{g} / \mathrm{l}$ above which macrophyte abundance was far less pronounced; further the model of these authors shows that at a reference value for Chl.a of $3.1 \mu \mathrm{g} / \mathrm{l}$ macrophytes can reach a maximum colonisation depth of 4-6 m. The macrophytes in Lake Tegel reached these depths already at higher mean summer concentrations of Chl.a, i.e. in the range of 4-6 $\mu \mathrm{g} / \mathrm{l}$ (Fig. 11).

With respect to the low abundance of Charophytes, the macrophytes in Lake Tegel have not yet reached target conditions for ecological quality. Sand-Jensen et al. (2017) proposed that the disappearance of many species from the pool of propagules in a lake and its catchment can preclude the re-establishment of those originally present before anthropogenic eutrophication. However, Chara have re-established populations in Scharmützelsee near Berlin already 10 years ago (Hilt et al., 2010a) and since the mid-2010s macrophyte coverage has increased beyond expectation also in the wider area around Berlin. Intrusion of Havel River water can contribute to seeding Lake Tegel with propagules, and thus reaching a good ecological quality may yet be realistic. These results suggest that, for macrophytes also, resilience against reoligotrophication may be less pronounced than expected.

As the benthic biota are still undergoing dynamic changes in the wake of macrophyte re-colonisation, and with Secchi depths now frequently ranging well above 4-5 m, more than half of the lake's sediment surface is now within the euphotic zone. Therefore, developments in this large littoral zone can have a major impact on the biota and their interaction with the

\footnotetext{
${ }_{3}$ Following the PHYLIB approach from category 3.5 in 2007 to 2.4 in 2016; following the LANAPLAN approach from category 5 to category 3 (both approaches including 5 categories); the LANAPLAN approach is more appropriate because of the still low amounts of Characeae.
} 
P budget. As the macrophyte cover largely consists of the water moss Fontinalis (which attaches to surfaces but does not establish roots into the sediment), we can exclude relevance of macrophytes as "benthic shunt" as described by Hecky et al. (2004) for transporting P from deeper sediment layers first into macrophyte biomass - and when this decomposes also into the water.

However, although quantitative data on the mussel populations are yet lacking it is well known, including from other Berlin waterbodies (Wegner et al., 2019), that an increase in macrophyte coverage serves as substrate for colonisation with large populations of small mussels. Since decades, sporadic informal observations at Lake Tegel have emphasised the substantial amount of Dreissena in the lake. While their filtration rate can contribute to loss rates in the phytoplankton, thus reducing its biomass, it can also substantially contribute to the liberation of phosphorus by enhancing the mineralisation of recently sedimented organic material. With the Quagga mussel Dreissena rostriformis bugensis recently spreading in Berlin's waterways (Wegner et al., 2019), it is therefore currently unclear which impact mussels will have on the further trophic development of Lake Tegel. Furthermore, growth of the mussel population may lead to competition with macrophytes for space on the sediment (Wegner et al., 2019), and changes in macrophyte composition may lead to phases of their decomposition.

The increased macrophyte cover also serves as a new substrate for associated tychoplanktonic and toxin-producing cyanobacteria: Fastner et al. (2018) report the intoxication of $12 \mathrm{dogs}$, some fatal, after ingestion of detached clumps of Fontinalis beached at the shores of Lake Tegel; high levels of the cyanotoxin anatoxin-a were found in their stomachs together with Fontinalis and Tychonema. Analyses of the lake water both between macrophyte stands and in pelagic samples found anatoxin-a only very occasionally and at concentrations well below $<1 \mu \mathrm{g} / \mathrm{l}$. A health hazard through recreational use of the lake appeared unlikely other than through the ingestion of floating or beached clumps of Fontinalis; however, intoxication and death of dogs in such numbers certainly raises concern. Salmaso et al. (2016) also associated anatoxins found in Lake Garda to Tychonema bourrellyi and emphasise that this species is becoming widespread in three other pre-alpine lakes in the wake of their recovery from eutrophication-in Lake Garda it is now more prevalent than the previously dominant toxin-producing Planktothrix rubescens. While it is well known that a number of benthic cyanobacteria can produce toxins and have caused fatal intoxication particularly of dogs (see overview in Fastner et al., 2018), the role of benthic macrophytes in serving as substrate for their proliferation generally has been poorly studied.

Thus, it is unclear which effects the still changing benthic community will have on phytoplankton during the years to come, particularly if reduced PEP operation will—once again-lead to higher concentrations of TP and phytoplankton, lower transparency and possibly lesser macrophyte coverage, a-so far slight-trend indicated by the most recent data for 2017-2019.

\section{Conclusions: resilience, thresholds and hysteresis}

In contrast to widespread concerns also voiced at the beginning of the restoration of Lake Tegel, the results of this case study show that legacy $\mathrm{P}$, even in a sapropelic sediment with a long loading history, need not cause massive resilience against re-oligotrophication, provided load reduction is sufficiently pronounced and the water residence time is low enough. The concentration of TP in the lake water directly responded to changes in the external loads: on a seasonal scale this shows in the autumn peaks in the water of Lake Tegel which trace those of the Havel River inflow at the south-west. On an annual scale, however, the strongly reduced load from the PEP at the north-east allowed the sediments to become a sink rather than a source for $\mathrm{P}$ within a few years. Thus, for the annual TP budget the throughflow from the PEP was decisive, and TP concentrations in the lake decreased in the wake of PEP-water throughflow. In consequence, confirming our first hypothesis, Lake Tegel needed no further measures other than steady operation of the PEP to maintain a sufficient turnover rate with low-P water counteracting Havel River inflow.

Some thresholds for responses were relevant but these do not imply resilience; rather, they occurred in the range expected from the mechanisms of ecological interaction: phytoplankton biomass cannot respond to reduced TP concentrations until these decline to a 
concentration range that limits the carrying capacity for biomass. Chrysophytes will not grow while massive primary production causes a high $\mathrm{pH}$, and macrophytes cannot re-colonise in turbid water; also, it takes years for their propagules to grow to sizable populations. Resilience scarcely occurred: internal $\mathrm{P}$ loading from the sediment contributed only a minor fraction of the concentration in the lake. Phytoplankton biomass largely followed the changes in TP quite closely, once concentrations of this nutrient were in the range limiting the standing stock of biomass. Zooplankton biomass followed that of phytoplankton (with some support through concomitant changes in the fish population). Macrophytes returned to a larger extent and with more recovery of species composition than expected. Thus, the results for the restoration of Lake Tegel do not confirm our second hypothesis, i.e. that some resilience is to be expected.

Where phytoplankton showed resilience in the sense of delayed responses, it was during the phases of "re-eutrophication": In 1997-2001 Microcystis did not return to the levels that TP concentrations would have supported, and in the 3 years with elevated concentrations of TP since 2016 new pronounced maxima of Ceratium spp. and Dinobryon spp. appeared only in the 3rd year. Some ecosystem components showed positive feedback loops, supporting the re-oligotrophication process: lower phytoplankton productivity enabled vivianite formation, enhancing permanent loss of $\mathrm{P}$ to the sediment. It also increased transparency, thus cracking the dominance of cyanobacteria for the benefit of phytoplankton species with higher loss rates as well as macrophyte recolonisation, and both contributed to keeping the water clear.

The concept of hysteresis proposes a stronger trigger to be necessary to induce change in a lake undergoing oligotrophication as compared to one undergoing eutrophication. The decline of TP concentrations from a summer mean of $44 \mu \mathrm{g} / \mathrm{l}$ in 1993 to $29 \mu \mathrm{g} / \mathrm{l}$ in 1994 was a strong trigger. However, the phytoplankton population was maximally exploiting TP for biomass formation in the two preceding years, as reflected by the high ratios of both Chl.a and biovolume to TP in 1992 and 1993. Thus, a biomass response would probably have also occurred if the decline of the TP concentrations had not been quite as pronounced. In contrast, the resistance seen for the Microcystis population during the two short phases of re-eutrophication in Lake Tegel could be interpreted as hysteresis in the reversed sense-as a strong trigger being necessary to revert the phytoplankton population to being dominated by cyanobacteria and reach the high levels of biomass that TP would have supported. All in all, Lake Tegel shows that the observation that Jeppesen et al. (2007) derived for shallow lakes, i.e. that hysteresis of a restoration response appears to be of lesser relevance than originally proposed, also holds for this thermally stratified lake.

We can conclude that

1. If the turnover rate with 'low-P-water' is high enough, i.e. in the range of several times per year, even a thick sapropelic layer of sediment rich in legacy P need not preclude restoration success, as $P$ released from the sediment will be diluted and exported;

2. The sediment can become a sink rather than a source for $\mathrm{P}$ once substantially less biomass settles to the bottom and therefore less $\mathrm{P}$ is released through mineralisation (if the key process determining $\mathrm{P}$ release is mineralisation rather than redox-sensitive liberation of $\mathrm{P}$ adsorbed to iron);

3. As P limitation becomes increasingly stringent, phytoplankton may exploit the available amount with increasing efficiency but only up to a turning point: once TP concentrations decline below a threshold, it will limit the standing stock and force it to decrease, rendering the water clearer;

4. Changes in the underwater light climate affect the outcome of competition between phytoplankton species, and this can trigger a regime shift in species composition;

5. At epilimnetic $\mathrm{TP} \leq 30 \mu \mathrm{g} / \mathrm{l}$, resilience mechanisms (such as the potential vertical migration of Microcystis spp. for replenishing cellular P stocks) are not likely to be sufficiently effective to compensate $\mathrm{P}$ limitation and maintain the previously prevalent blooms;

6. Bringing TP concentrations down into the range of $30 \mu \mathrm{g} / \mathrm{l}$ can break cyanobacterial dominance, and further reducing TP to less than $20 \mu \mathrm{g} / \mathrm{l}$ can reliably limit their biomass to negligible levels;

7. If the substantial decline in phytoplankton biomass renders water sufficiently clear, submerged macrophytes will return. 
The case study of Lake Tegel shows, however, that these processes of trophic recovery take time to cascade through the trophic levels, even if the load reduction is substantial and the water exchange rate is high.

It is very clear that the approach of stripping $\mathrm{P}$ from the main tributary, successful as it was for Lake Tegel, cannot readily be transferred to waterbodies with more diffuse loading and/or less water available for diluting the $\mathrm{P}$ content. A meta-analysis of restoration case studies including not only TP concentrations in the waterbodies but also flushing rates would therefore be important as basis for better predictions of the time scales needed for trophic recovery. It is therefore important to make data series on trophic recovery broadly available and internationally well accessible to those who are striving to analyse the impact of changes across a range of waterbodies and regions, be they through nutrient loading or climate warming. For this purpose, the data used here have been deposited in LakeBase (FRED, the Freshwater Research and Environmental Database).

Acknowledgements The basic nutrient and phytoplankton data available from the monitoring of the lake's development were substantially enriched by range of research projects, diploma- and $\mathrm{PhD}$-theses which focused on specific ecosystem components (see Chorus \& Schauser 2011 for a compilation). We are grateful for their contributions both to the overall database and to the understanding of the ecosystem as well as for the funding of the respective research projects. Those who now enjoy clear Lake Tegel owe a lot to the initiative and the persistence of the pioneers who had the idea of putting a PEP at the lake's main inflow (Ulrich Hässelbarth), who developed much of the chemotechnical approach (Andreas Grohmann), who monitored the lake's response during the early years (Günter Klein), the decision makers in the city government who raised funds for the investments (Rudolf Kloos and Dietrich Jahn) and the Berlin Waterworks who are ensuring reliable operation since decades. Special thanks go to almost countless technicians who conducted sampling in wind and weather, chemical analyses and plankton counting over decades. We thank Sabine Hilt for valuable discussions of the role of macrophyte cover and mussels as well as Ursula Gaedke, Niina Kotamäki and Jasmin Peisker for fruitful discussions of options for statistical evaluation. We thank Helmut Fischer and Manuel Pérez Mayo (University Bremen) for sediment dating, Lena Heinrich (TU Berlin, IGB) for the participation on sediment sampling and analysis and Iris Pribilla for critically checking the manuscript. The work was partly funded by the German Research Foundation (DFG) as part of the ongoing Research Training Group "Urban Water Interfaces (UWI)" (GRK $2032 / 1+2$ ) which selected Lake Tegel as one of the key study sites. Last but by no means least - and as an excellent model for lake management-we thank the annual round table of all those in Berlin who are involved with the restoration of Lake Tegel for these regular, very fruitful discussions of the lake's progress in recovering from its hypertrophic state.

Open Access This article is licensed under a Creative Commons Attribution 4.0 International License, which permits use, sharing, adaptation, distribution and reproduction in any medium or format, as long as you give appropriate credit to the original author(s) and the source, provide a link to the Creative Commons licence, and indicate if changes were made. The images or other third party material in this article are included in the article's Creative Commons licence, unless indicated otherwise in a credit line to the material. If material is not included in the article's Creative Commons licence and your intended use is not permitted by statutory regulation or exceeds the permitted use, you will need to obtain permission directly from the copyright holder. To view a copy of this licence, visit http://creativecommons.org/licenses/by/4.0/.

Funding Open Access funding enabled and organized by Projekt DEAL.

\section{References}

Adrian, R., J.M. Keil, B. König-Ries, S. Frenzel, D. Langenhaun, A. Boit, U. Gaedke, P. Kasprzak, L. Paul, K.-O. Rothaupt, D. Straile \& A. Wagner: in prep.: LakeBase: a data infrastructure for long-term data of German Lakes.

Anneville, O., V. Ginot \& N. Angeli, 2002. Restoration of Lake Geneva: expected versus observed responses of phytoplankton to decreases in phosphorus. Lakes \& Reservoirs: Research \& Management 7: 67-80.

Baastrup-Spohr, L., K. Sand-Jensen, S. C. Olesen \& H. H. Bruun, 2017. Recovery of lake vegetation following reduced eutrophication and acidification. Freshwater Biology 62: 1847-1857.

Bai, J. \& P. Perron, 2003. Computation and analysis of multiple structural change models. Journal of Applied Econometrics 18: $1-22$.

Barko, J. W. \& W. F. James, 1998. Effects of submerged aquatic macrophytes on nutrient dynamics, sedimentation and resuspension. In Jeppesen, E., M. Sondergaard \& K. Chistoffersen (eds), The Structuring Role of Submerged Macrophytes in Lakes. Springer, New York: 197-214.

Brunberg, A. K. \& P. Blomqvist, 2003. Recruitment of Microcystis (Cyanophyceae) from lake sediments: the importance of littoral inocula. Journal of Phycology 39: 58-63.

Carvalho, L., C. McDonald, C. de Hoyos, U. Mischke, G. Philipps, G. Borics, S. Poikane, B. Skjelbred, A. Lyche Solheim, J. van Wichelen \& A. C. Cardoso, 2013. Sustaining recreational quality of European lakes: minimizing the health risks from algal blooms through phosphorus control. Journal of Applied Ecology 50: 315-323.

Chorus, I. \& G. Schlag, 1993. Importance of intermediate disturbances for the species composition and diversity of phytoplankton in two very different Berlin lakes. Hydrobiologia 249: 67-92. 
Chorus, I. \& I. Schauser, 2011. Oligotrophication of Lake Tegel and Schlachtensee, Berlin-analysis of system components, causalities and response thresholds compared to responses of other waterbodies. UBA Texte 45: 2011.

Chorus, I., \& E. Spijkerman, 2020. What Colin Reynolds could tell us about nutrient limitation, N: P ratios and eutrophication control. Hydrobiologia, 1-17.

Chorus, I., G. Klein, J. Fastner \& W. Rotard, 1992. Off-flavors in surface waters-How efficient is bank filtration for their abatement in drinking water? Water Science and Technology 25(2): 251-258.

Deneke, R., G. Maier \& U. Mischke, 2015. Das PhytoLossVerfahren. Berücksichtigung des Zooplanktons in der Seenbewertung nach EU-WRRL durch die Ermittlung der Grazing-Effektstärke und anderer Indizes. Ausführliche Verfahrensvorschrift. Stand: März 2015, Version 2.0. Im Auftrag der LAWA (Länderarbeitsgemeinschaft Wasser, Expertenkreis Seen), Projekt O8.12 (Projektmodul PhytoLoss), Berlin.

Dolman, A. M., J. Rücker, F. R. Pick, J. Fastner, T. Rohrlack, U. Mischke \& C. Wiedner, 2012. Cyanobacteria and cyanotoxins: the influence of nitrogen versus phosphorus. PLoS ONE 7: e38757.

Evans, M. A., G. Fahnenstiel \& D. Scavia, 2011. Incidental oligotrophication of North American Great Lakes. Environmental Science \& Technology 45: 3297-3303.

Fastner, J., S. Abella, A. Litt, G. Morabito, L. Vörös, K. Pálffy \& I. Chorus, 2016. Combating cyanobacterial proliferation by avoiding or treating inflows with high $\mathrm{P}$ load-experiences from eight case studies. Aquatic Ecology 50: 367-383.

Fastner, J., C. Beulker, B. Geiser, A. Hoffmann, R. Kröger, K. Teske \& I. Chorus, 2018. Fatal neurotoxicosis in dogs associated with tychoplanktic, anatoxin-a producing $T y$ chonema sp. in mesotrophic lake Tegel Berlin. Toxins 10: 60.

Gächter, R. \& B. Müller, 2003. Why the phosphorus retention of lakes does not necessarily depend on the oxygen supply to their sediment surface. Limnology \& Oceanography 48 : 929-933.

Grüneberg, B., T. Dadi, C. Lindim \& H. Fischer, 2015. Effects of nitrogen and phosphorus load reduction on benthic phosphorus release in a riverine lake. Biogeochemistry 123: 185-202.

Hecky, R. E., R. E. Smith, D. R. Barton, S. J. Guildford, W. D. Taylor, M. N. Charlton \& T. Howell, 2004. The nearshore phosphorus shunt: a consequence of ecosystem engineering by dreissenids in the Laurentian Great Lakes. Canadian Journal of Fisheries and Aquatic Sciences 61: 1285-1293.

Heinrich, L., 2016. Impact of management measures on sediment stratigraphy and phosphorus fixation in Lake Tegel (Berlin). Master thesis, TU Berlin, p. 66

Heinzmann, B. \& F. Sarfert, 1990. Die Phosphateliminationsanlage Beelitzhof in Berlin (West). Gwf-Wasser/Abwasser 131: 262-269.

Heinzmann, B. \& I. Chorus, 1994. Restoration concept for Lake Tegel, a major drinking and bathing water resource in a densely populated area. Environmental Science \& Technology 28: 1410-1416.

Hilt, S., I. Henschke, J. Rücker \& B. Nixdorf, 2010a. Can submerged macrophytes influence turbidity and trophic state in deep lakes? Suggestions from a case study. Journal of Environmental Quality 39: 725-733.

Hilt, S., K. Van de Weyer, A. Köhler \& I. Chorus, 2010 b. Submerged macrophyte responses to reduced phosphorus concentrations in two peri-urban lakes. Restoration Ecology 18: 452-461.

Horn, W. \& H. Horn, 1995. Interrelationships between crustacean zooplankton and phytoplankton: results from 15 years of field observations at the mesotrophic Saidenbach Reservoir (Germany). Hydrobiologia 307: 231-238.

Hupfer, M. \& S. Hilt, 2008. Lake restoration. In Jørgensen, S. E. \& B. D. Fath (eds), Encyclopedia of Ecology, Vol. 3. Elsevier, Oxford: 2080-2093.

Hupfer, M., K. Reitzel, A. Kleeberg \& J. Lewandowski, 2016. Long-term efficiency of lake restoration by chemical phosphorus precipitation. Water Research 97: 153-161.

Ihle, T., S. Jähnichen \& J. Benndorf, 2005. Wax and wane of microcystis and microcystins in lake sediments: a case study in Quitzdorf reservoir (Germany). Journal of Phycology 41: 479-488.

Jeppesen, E., M. Søndergaard, J. P. Jensen, K. Havens, O. Anneville, L. Carvalho, M. F. Coveney, R. Deneke, M. Dokulil, B. Foy, D. Gerdeaux, S. E. Hampton, K. Kangur, J. Köhler, S. Körner, E. Lammens, T. L. Lauridsen, M. Manca, R. Miracle, B. Moss, P. Noges, G. Persson, G. Phillips, R. Portielje, S. Romo, C. L. Schelske, D. Straile, I. Tatrai, E. Wille'n \& M. Winder, 2005. Lake responses to reduced nutrient loading — an analysis of contemporary long-term data from 35 case studies. Freshwater Biology 50: 1747-1771.

Jeppesen, E., M. Sondergaard, M. Meerhoff, T. L. Lauridsen \& J. P. Jensen, 2007. Shallow lake restoration by nutrient loading reduction-some recent findings and challenges ahead. Hydrobiologia 584: 239-252.

Kleeberg, A., A. Köhler \& M. Hupfer, 2012. How effectively does a single or continuous iron supply affect the phosphorus budget of aerated lakes? Jounal of Soils and Sediments 12: 1593-1603.

Klein, G., 1992. Rationale and implementation of a strategy to restore urban lakes in Berlin: results after ten years of phosphorus removal. Water Quality Research Journal 27: 239-256.

Kohler, A., 1978. Methoden der Kartierung von Flora und Vegetation von Süßwasserbiotopen. Landschaft und Stadt 10: 73-85.

Ladwig, R., L. Heinrich, G. Singer \& M. Hupfer, 2017. Sediment core data reconstruct the management history and usage of a heavily modified urban lake in Berlin, Germany. Environmental Science and Pollution Research 24: 25166-25178.

Lanaplan, 2006. Entwicklung einer Methode zur Kartierung der Unterwasservegetation an großen Seen am Beispiel des Schaalsees und seiner angrenzenden Nebengewässer zur Erfüllung des operativen EG-WRRL-Monitorings und FFH-Monitorings, Gutachten im Auftrag des LANU Schleswig-Holstein, Flintbeck. www.umweltdaten.landsh.de/ nuis/wafis/seen/Berichte_Gutachten/Ufer_ Unterwasservegetation/Bericht_Makrophyten_2005_ Schaalsee_vdWeyer.pdf. 
Lindenschmidt, K. E. \& I. Chorus, 1997. The effect of aeration on stratification and phytoplankton populations in Lake Tegel, Berlin. Archiv für Hydrobiologie 139: 317-346.

Mantzouki, E., P. M. Visser, M. Bormans \& B. W. Ibelings, 2016. Understanding the key ecological traits of cyanobacteria as a basis for their management and control in changing lakes. Aquatic Ecology 50: 333-350.

Morabito, G., A. Oggioni, \& E. Caravati, 2005. Decadal trends of pelagic algal biomass capacities in Lago Maggiore (N. Italy). Verhandlungen der Internationalen Vereinigung für Limnologie 29: 231-234.

Olsen, S., F. Chan, S. Zhao, M. Søndergaard \& E. Jeppesen, 2015. Strong impact of nitrogen loading on submerged macrophytes and algae: a long-term mesocosm experiment in a shallow Chinese lake. Freshwater Biology 60: 1525-1536.

Paerl, H. W., K. E. Havens, H. Xu, G. Zhu, M. J. McCarthy, S. E. Newell, B. Qin, et al., 2019. Mitigating eutrophication and toxic cyanobacterial blooms in large lakes: the evolution of a dual nutrient ( $\mathrm{N}$ and $\mathrm{P}$ ) reduction paradigm. Hydrobiologia. https://doi.org/10.1007/s10750-01904087-y.

Phillips, G., O. P. Pietiläinen, L. Carvalho, A. Solimini, A. Lyche Solheim \& A. C. Cardoso, 2008. Chlorophyll-nutrient relationships of different lake types using a large European dataset. Aquatic Ecology 42: 213-226.

Polkane, S., R. Portielje, M. I. van den Berg, G. Phillips, S. Brucet, L. Carvalho, U. Mischke, I. Ott, H. Soszka \& J. van Wichelen, 2014. Defining ecologically relevant water quality targets for lakes in Europe. Journal of Applied Ecology 51: 592-602.

Preston, T., W. D. P. Stewart \& C. S. Reynolds, 1980. Bloomforming cyanobacterium Microcystis aeruginosa overwinters on sediment surface. Nature 288: 365-367.

R Development Core Team. 2018. R: a language and environment for statistical computing. R foundation for statistical computing, Vienna, Austria. http://www.r-project.org/.

Reynolds, C. S., G. H. M. Jaworski, H. A. Cmiech \& G. F. Leedale, 1981. On the annual cycle of the blue-green alga Microcystis aeruginosa Kütz. emend. Elenkin. Proceedings of the Royal Society of London Series B 293: 419-477.

Reynolds, C. S., V. L. M. Huszar, C. Kruk, L. Naselli-Flores \& S. Melo, 2002. Towards a functional classification of the freshwater phytoplankton. Journal of Plankton Research 24: 417-442.

Richardson, J., C. Miller, S. C. Maberly, P. Taylor, L. Globevnik, P. Hunter \& M. Søndergaard, 2018. Effects of multiple stressors on cyanobacteria abundance vary with lake type. Global Change Biology 24: 5044-5055.

Ripl, W., S. Heller, B. Koppelmeyer, M. Markwitz, \& K.-D. Wolter, 1993. Limnologische Begleitstudie zur Entlastung des Tegeler Sees. Report for the environment administration of the Senate of Berlin.

Rothe, M., A. Kleeberg, B. Grüneberg, K. Friese, M. PerezMayo \& M. Hupfer, 2015. Sedimentary sulphur: iron ratio indicates vivianite occurrence. PLoS ONE 10: e0143737.

Salmaso, N., L. Cerasino, A. Boscaini \& C. Capelli, 2016. Planktic Tychonema (cyanobacteria) in the large lakes south of the Alps: phylogenetic assessment and toxigenic potential. FEMS Microbiology Ecology 92: fiw155.
Salmaso, N., A. Boscaini, C. Capelli \& L. Cerasino, 2018. Ongoing ecological shifts in a large lake are driven by climate change and eutrophication: evidences from a threedecade study in Lake Garda. Hydrobiologia 824: 177-195.

Sand-Jensen, K., H. H. Bruun \& L. Baastrup-Spohr, 2017. Decade-long time delays in nutrient and plant species dynamics during eutrophication and re-oligotrophication of Lake Fure 1900-2015. Journal of Ecology 105: 690-700.

Sas, H., 1989. Lake restoration by reduction of nutrient loading: expectations, experiences, extrapolations. Academia Verlag Richarz, p. 479

Schaumburg, J., C. Schranz, D. Stelzer \& A. Vogel, 2015. Verfahrensanleitung für die ökologische Bewertung von Seen zur Umsetzung der EG-Wasserrahmenrichtlinie: Makrophyten \& Phytobenthos-Phylib,-Stand Februar 2014. Bayerisches Landesamt für Umwelt, München.

Schauser, I. \& I. Chorus, 2007. Assessment of the success of internal and external lake restoration measures in two Berlin lakes. Lake and Reservoir Management 23: 366-376.

Schauser, I. \& I. Chorus, 2009. Water and phosphorus mass balance of Lake Tegel and Schlachtensee-a modelling approach. Water Research 43: 1788-1800.

Schauser, I., I. Chorus \& B. Heinzmann, 2006a. Strategy and current status of combating eutrophication in two Berlin lakes for safeguarding drinking water resources. Water Science and Technology 54: 93-100.

Schauser, I., I. Chorus \& J. Lewandowski, 2006b. Effects of nitrate on phosphorus release: comparison of two Berlin lakes. Acta Hydrochimica et Hydrobiologica 34: 325-332.

Scheffer, M., 1989. Alternative stable states in eutrophic shallow freshwater systems- a minimal model. Hydrobiological Bulletin 23: 73-83.

Scheffer, M., S. Rinaldi, A. Gragnani, L. R. Mur \& E. H. van Nes, 1997. On the dominance of filamentous cyanobacteria in shallow, turbid lakes. Ecology 78: 272-282.

Schimmelpfennig, S., G. Kirillin, C. Engelhardt, G. Nützmann \& U. Dünnbier, 2012. Seeking a compromise between pharmaceutical pollution and phosphorus load: management strategies for Lake Tegel, Berlin. Water Research 46: 4153-4163.

Schimmelpfenning, S., G. Kirillin, C. Engelhardt, U. Dünnbier \& G. Nützmann, 2016. Fate of pharma-ceutical micropollutants in lake Tegel (Berlin, Germany): the impact of lake- specific mechanisms. Environmental Earth Sciences 75: 893 .

Schindler, D. W., 2012. The dilemma of controlling cultural eutrophication of lakes. Proceedings of the Royal Society B 279(1746): 4322-4433.

Senate, 2017. Sediment investigations in Lake Tegel (in German), unpubl. report, p. 25.

Succow, M. \& D. Kopp, 1985. Seen als Naturraumtypen. Petermanns Geographische Mitteilungen 3: 161.

Topachevskiy, A. V., L. P. Braginskiy \& L. A. Sirenko, 1969. Massive development of blue-green algae as a product of the ecosystem of a reservoir. Hydrobiological Journal 5: $1-10$.

Tümpling, W. \& G. Friedrich, 1999. Methoden der biologischen Wasseruntersuchung, Vol. 2. Biologische Gewässeruntersuchung, Gustav Fischer, Jena. 
Utermöhl, H., 1958. Zur Vervollkommnung der quantitativen Phytoplankton-Methodik. Verhandlungen der Internationalen Vereinigung der Limnologie 9: 1-27.

van de Weyer, K. \& C. Schmidt, 2018. Bestimmungsschlüssel für die aquatischen Makrophyten (Gefäßpflanzen, Armleuchteralgen und Moose) in Deutschland: Band 1: Bestimmungsschlüssel. 2., überarbeitete Auflage. Fachbeiträge des LfU Brandenburg 119: 180 S. Herausgeber: Landesamt für Umwelt (LfU) Brandenburg, Potsdam.

Verspagen, J. M., E. O. Snelder, P. M. Visser, K. D. Joehnk, B. W. Ibelings, L. R. Mur \& J. E. F. Huisman, 2005. Benthicpelagic coupling in the population dynamics of the harmful cyanobacterium Microcystis. Freshwater Biology 50: 854-867.

Vollenweider, R. A., 1976. Advances in defining critical loading levels for phosphorus in lake eutrophication. Memorie dell'Istituto Italiano di Idrobiologia 33: 53-84.

Vollenweider, R., J. Kerekes, 1982. Eutrophication of waters: monitoring, assessment, control organisation for economic cooperation and development, Paris

Vuorio, K., M. Järvinen \& N. Kotamäki, 2019. Phosphorus thresholds for bloom-forming cyanobacterial taxa in boreal lakes. Hydrobiologia, 1-12.

Wegner, B., A. L. Kronsbein, M. Gillefalk, K. van de Weyer, J. Köhler, E. Funke \& S. Hilt, 2019. Mutual facilitation among invading Nuttall's waterweed and quagga mussels. Frontiers in Plant Science 10: 789.

Winder, M. \& U. Sommer, 2012. Phytoplankton response to a changing climate. Hydrobiologia 698: 5-16.
Zeileis, A., F. Leisch, K. Hornik \& C. Kleiber, 2002. Strucchange: an $\mathrm{R}$ package for testing for structural change in linear regression models. Journal of Statistical Software 7: $1-38$.

Zeileis, A., C. Kleiber, W. Kraemer \& K. Hornik, 2003. Testing and dating of structural changes in practice. Computational Statistics and Data Analysis 44: 109-123.

Zessner, M. 1999: Bedeutung und Steuerung von Nährstoff und Schwermetallflüssen des Abwassers. Institute for Water Quality, Resources and Waste Management. University of Vienna, Vienna. AU

Chorus, I. \& V. Niesel: Steps towards a statistical model to predict phytoplankton responses to changes in trophic state. In: Chorus, I., \& I. Schauser, 2011 (eds.). Oligotrophication of Lake Tegel and Schlachtensee, BerlinAnalysis of system components, causalities and response thresholds compared to responses of other waterbodies. UBA Texte, 45, 2011: 106-139

FRED. See https://doi.org/10.18728/557.0 for Lake Tegel physico-chemical data and https://doi.org/10.18728/558.0 for Lake Tegel Phytoplankton data

Reynolds, C. S., 1997: Vegetation Processes in the Pelagic: A Model for Ecosystem Theory. Ecology Institute, Oldendorf/Luhe.

Sterner, R. W., 2008. On the phosphorus limitation paradigm for lakes. International Review of Hydrobiology 93: 433-445.

Publisher's Note Springer Nature remains neutral with regard to jurisdictional claims in published maps and institutional affiliations. 